\title{
SOIL MICROBIAL CONTROL OF NITROGEN LOSS FOLLOWING CLEAR- CUT HARVEST IN NORTHERN HARDWOOD ECOSYSTEMS
}

\author{
William E. Holmes and Donald R. ZaK ${ }^{1}$ \\ University of Michigan, School of Natural Resources and Environment, 430 East University, \\ Ann Arbor, Michigan 48109-1115 USA
}

\begin{abstract}
Establishing the relationship among the spatial distribution of forest ecosystems, $\mathrm{N}$ cycling processes, and $\mathrm{N}$ loss following harvesting could enable land managers to anticipate and predict the potential for $\mathrm{N}$ loss at the scale of local and regional landscapes. In the Great Lakes region, northern hardwood forests with distinct floristic, edaphic, and physiographic characteristics vary predictably across the landscape in $\mathrm{N}$ cycling processes, especially in rates of nitrification. Although their landscape distribution and patterns of $\mathrm{N}$ cycling are well established, it is uncertain whether this type of information could be used to predict landscape-level patterns of $\mathrm{N}$ loss following overstory harvest or other types of disturbance.
\end{abstract}

We studied the microbial processes in soil that control the retention and loss of $\mathrm{N}$ following clear-cutting in two northern hardwood ecosystems that are widely distributed in the upper Great Lakes states and differ floristically, edaphically, and in $\mathrm{N}$ cycling processes. The overstory of one hardwood ecosystem is dominated by Acer saccharum and Quercus rubra, and the other is dominated by A. saccharum and Tilia americana. These ecosystems differ in annual rates of net nitrification ( 5 vs. $15 \mathrm{~g} \mathrm{NO}_{3}^{-}-\mathrm{N} \cdot \mathrm{m}^{-2} \cdot \mathrm{yr}^{-1}$ ), and we studied paired intact and clear-cut plots within them to understand whether spatial patterns of nitrification could be used to predict $\mathrm{N}$ loss following harvest. We measured microbial biomass, $\mathrm{NO}_{3}^{-}$leaching, denitrification, and microbial $\mathrm{N}$ transformations for one year following a clear-cut harvest.

Clear-cut harvest led to significant loss of $\mathrm{N}$ through $\mathrm{NO}_{3}^{-}$leaching in both ecosystems, averaging $4.9 \mathrm{~g} \mathrm{~N} \cdot \mathrm{m}^{-2} \cdot \mathrm{yr}^{-1}$ in clear-cut plots and $0.2 \mathrm{~g} \mathrm{~N} \cdot \mathrm{m}^{-2} \cdot \mathrm{yr}^{-1}$ in intact plots. Denitrification was low in both ecosystems $\left(0.08-0.42 \mathrm{~g} \mathrm{~N} \cdot \mathrm{m}^{-2} \cdot \mathrm{yr}^{-1}\right)$ and did not increase significantly following clear-cutting $\left(0.16-0.29 \mathrm{~g} \mathrm{~N} \cdot \mathrm{m}^{-2} \cdot \mathrm{yr}^{-1}\right)$. Averaged across ecosystems, annual net $\mathrm{N}$ mineralization increased by a factor of 2 in clear-cut plots $\left(14.2 \mathrm{~g} \mathrm{~N} \cdot \mathrm{m}^{-2} \cdot \mathrm{yr}^{-1}\right)$ relative to intact plots $\left(7.3 \mathrm{~g} \mathrm{~N} \cdot \mathrm{m}^{-2} \cdot \mathrm{yr}^{-1}\right)$; net nitrification similarly increased after harvest (11.4 $\mathrm{g} \mathrm{N} \cdot \mathrm{m}^{-2} \cdot \mathrm{yr}^{-1}$ clear-cut vs. $5.5 \mathrm{~g} \mathrm{~N} \cdot \mathrm{m}^{-2} \cdot \mathrm{yr}^{-1}$ intact). Gross rates of $\mathrm{N}$ mineralization and nitrification displayed a response similar to that of net rates. Although gross rates of $\mathrm{N}$ immobilization increased following clear-cutting, microbial biomass did not change. Thus, increased turnover of $\mathrm{N}$ through microbial biomass ([biomass $\mathrm{N}] /[$ gross $\mathrm{N}$ immobilization]) resulted in the observed increase in net $\mathrm{N}$ mineralization rates. Our results indicate that microbial immobilization of $\mathrm{N}$ was not an important process of $\mathrm{N}$ retention following clear-cut harvest in sugar maple-dominated northern hardwood forests. Rather, increases in net $\mathrm{N}$ mineralization following harvest increased substrate availability to nitrifying bacteria, which eventually resulted in substantial losses of $\mathrm{N}$ through leaching. Regardless of initial differences in net nitrification, harvesting led to similar rates of rates $\mathrm{NO}_{3}{ }^{-}$leaching from both northern hardwood ecosystems. We conclude that $\mathrm{N}$ loss following clear-cutting in these forests cannot be predicted by rates of nitrification prior to harvest. Rather, $\mathrm{N}$ loss depends on high initial rates of net $\mathrm{N}$ mineralization and on the effects of changes in microclimatic conditions and heterotrophic activity on $\mathrm{NH}_{4}^{+}$availability to nitrifying bacteria following overstory removal.

Key words: clear-cut; denitrification; harvest; Great Lakes region; microbial biomass; $N$ immobilization; $N$ leaching; $N$ mineralization; nitrification; nitrogen cycling; northern hardwoods; sugar maple.

\section{INTRODUCTION}

The implementation of ecosystem management is founded on detailed knowledge of ecological processes

Manuscript received 18 August 1997; revised 13 March 1998; accepted 23 March 1998.

${ }^{1}$ Address correspondence to this author. E-mail: drzak@umich.edu and the interrelationships among them at specific spatial and temporal scales (Christensen et al. 1996). Consequently, our ability to predict the effects of management practices on the nitrogen $(\mathrm{N})$ cycle of forests requires an understanding of the factors controlling $\mathrm{N}$ cycling at an ecosystem scale. In the Great Lakes region, forest ecosystems with distinct floristic and 
edaphic properties differ predictably in $\mathrm{N}$ cycling processes (Pastor et al. 1984, Zak et al. 1989, Zak and Pregitzer 1990). These ecosystem attributes suggest that forest harvesting may alter $\mathrm{N}$ cycling in an ecosystem-specific manner, presenting the possibility that the potential for $\mathrm{N}$ loss is predictable for a particular ecosystem. Given that ecosystems occur in a repeatable pattern across the landscape (Barnes et al. 1982), understanding the ecosystem-specific response of $\mathrm{N}$ cycling to forest management could enable land managers to extrapolate point-specific ecological processes over broad geographic regions.

The effects of clear-cutting and whole-tree harvesting on $\mathrm{N}$ loss have been studied extensively over the past 30 years in a variety of temperate forests. Northern hardwood forests are notable for their high potential for nitrate $\left(\mathrm{NO}_{3}^{-}\right)$leaching following disturbance (Bormann and Likens 1979, Hornbeck et al. 1986, Federer et al. 1989). Substantial hydrologic N losses during the first year following harvest have been linked to a sequence of events beginning with increased forest floor decomposition (i.e., greater rates of net $\mathrm{N}$ mineralization), which results in increased nitrification and the leaching of $\mathrm{NO}_{3}{ }^{-}$below the rooting zone (Hornbeck and Kropelin 1982, Vitousek et al. 1982, Dahlgren and Driscoll 1994). These studies point to the importance of soil organic matter and microbial activity in regulating $\mathrm{N}$ loss, particularly through the balance of $\mathrm{N}$ mineralization and immobilization.

Following overstory removal, soil microbial biomass can function as a sink for $\mathrm{N}$, thus minimizing or reducing $\mathrm{N}$ loss. Because microbial growth in soil is generally limited by C availability (Smith and Paul 1990), organic matter inputs from harvesting could increase gross $\mathrm{N}$ immobilization (relative to gross $\mathrm{N}$ mineralization) and decrease ammonium $\left(\mathrm{NH}_{4}{ }^{+}\right)$availability to nitrifying bacteria, thus reducing $\mathrm{NO}_{3}{ }^{-}$leaching and denitrification. Although microbial $\mathrm{N}$ immobilization is an important process of $\mathrm{N}$ retention in recently harvested loblolly pine (Pinus taeda L.) forests (Vitousek and Matson 1985), its importance in harvested northern hardwood forests is less certain.

The northern hardwood forests of the Great Lakes region occupy a range of site conditions and encompass a number of sugar maple (Acer saccharum Marsh.)dominated ecosystems differing in species composition and patterns of N cycling (Zak and Pregitzer 1990). Two widely distributed northern hardwood ecosystems dominated by sugar maple have similar rates of net $\mathrm{N}$ mineralization, but differ markedly in nitrification. A smaller proportion of mineralized $\mathrm{N}$ is oxidized to $\mathrm{NO}_{3}{ }^{-}$in northern hardwood forests in which northern red oak (Quercus rubra L., 9\% relative dominance) occurs as an overstory codominant, compared to those in which basswood (Tilia americana L., $25 \%$ relative dominance) occurs as an overstory species. Given the difference in nitrification rates between these ecosystems, their potential for $\mathrm{N}$ loss following harvest also should differ. Nevertheless, it is not clear whether northern hardwoods with lower nitrification rates lose less $\mathrm{NO}_{3}{ }^{-}$to leaching and denitrification following overstory removal.

Our objectives were (1) to determine the extent to which differences in nitrification rates among northern hardwood ecosystems influence $\mathrm{N}$ loss following harvesting, and (2) to assess the importance of $\mathrm{N}$ immobilization in reducing $\mathrm{N}$ loss by limiting the availability of $\mathrm{NH}_{4}^{+}$to nitrifying bacteria. We hypothesized that microbial $\mathrm{N}$ immobilization would increase following harvesting, due to an increase in the above and belowground input of organic matter. Therefore, microbial biomass could function as a temporary sink, retaining $\mathrm{N}$ that would otherwise be nitrified and lost through leaching or denitrification. Our approach was to measure microbial biomass, the gross and net transformations of $\mathrm{N}$ in soil, and loss of $\mathrm{N}$ through leaching and denitrification in clear-cut and intact northern hardwood ecosystems that differ in net nitrification.

\section{Methods \\ Study area}

We studied patterns of $\mathrm{N}$ retention and loss in two northern hardwood ecosystems, widely distributed throughout the upper Great Lakes states: the sugar maple-red oak-Maianthemum ecosystem and sugar maple-basswood-Osmorhiza ecosystem (hereafter "sugar maple-red oak" and "sugar maple-basswood" ecosystems). These ecosystems, classified using a multifactor approach (Barnes et al. 1982), differ in species composition, forest floor depths, soil $\mathrm{pH}$, soil organic matter content, and patterns of $\mathrm{N}$ cycling (Zak et al. 1986, 1989, Holmes and Zak 1994; Table 1). Annual net $\mathrm{N}$ mineralization rates are equivalent in the two ecosystems (average $13.7 \mathrm{~g} \mathrm{~N} \cdot \mathrm{m}^{-2} \cdot \mathrm{yr}^{-1}$ ), whereas annual net nitrification rates are significantly greater in the sugar maple-basswood ecosystem $\left(14.8 \mathrm{~g} \mathrm{~N} \cdot \mathrm{m}^{-2} \cdot \mathrm{yr}^{-1}\right)$ than in the sugar maple-red oak ecosystem (5.4 $\mathrm{g}$ $\mathrm{N} \cdot \mathrm{m}^{-2} \cdot \mathrm{yr}^{-1}$; Table 1$)$. Stands within each ecosystem type were located within the Huron-Manistee National Forest (Wexford County, $44^{\circ} 22^{\prime} \mathrm{N}, 85^{\circ} 30^{\prime} \mathrm{W}$, Fig. 1). The landscape is part of the Interlobate moraine, consisting of deep, glacial deposits of sand. Soils are welldrained, sandy, mixed, mesic Typic Haplorthods, developed in coarse-textured till ( $>90 \%$ sand). The area receives substantial snowpack in winter due to its location east of Lake Michigan at relatively high elevation (300-450 m). The growing season averages 115 $\mathrm{d}$, with mean annual temperature of $7.2^{\circ} \mathrm{C}$; annual precipitation of $81 \mathrm{~cm}$ is evenly distributed throughout the year (Albert et al. 1986).

\section{Trenching and clear-cutting}

Two stands were randomly selected from a group of three previously studied stands within each ecosystem (Zak and Pregitzer 1990). Four plots $(5 \times 30 \mathrm{~m})$ were 
TABLE 1. Overstory, soil, and N-cycling characteristics of two northern hardwood ecosystems in northern Lower Michigan, United States.

\begin{tabular}{|c|c|c|}
\hline Characteristics & $\begin{array}{l}\text { Sugar } \\
\text { maple- } \\
\text { red oak }\end{array}$ & $\begin{array}{c}\text { Sugar } \\
\text { maple-- } \\
\text { basswood }\end{array}$ \\
\hline \multicolumn{3}{|l|}{ Overstory } \\
\hline Age at harvest $(\mathrm{yr}) \dagger$ & 71 & 76 \\
\hline No. stems per ha $\dagger$ & 950 & 642 \\
\hline Aboveground biomass $(\mathrm{Mg} / \mathrm{ha}) \dagger$ & 260 & 242 \\
\hline Litterfall $\left(\mathrm{Mg} \cdot \mathrm{ha}^{-1} \cdot \mathrm{yr}^{-1}\right) \ddagger$ & 3.2 & 2.6 \\
\hline \multicolumn{3}{|l|}{$\mathrm{N}$ fluxes $\left(\mathrm{g} \mathrm{N} \cdot \mathrm{m}^{-2} \cdot \mathrm{yr}^{-1}\right)$} \\
\hline Atmospheric $\mathrm{N}$ deposition $\S$ & 1.2 & 1.2 \\
\hline Litterfall $\mathrm{N} \ddagger$ & 3.0 & 3.3 \\
\hline Net $\mathrm{N}$ mineralization $\dagger$ & 13.0 & 14.3 \\
\hline Net nitrification $\dagger$ & 5.4 & 14.8 \\
\hline $\mathrm{NH}_{4}^{+}+\mathrm{NO}_{3}^{-}$leaching $\|$ & 0.59 & 0.52 \\
\hline \multicolumn{3}{|l|}{ Soil, $0-10 \mathrm{~cm}$} \\
\hline $\mathrm{pH}_{\dagger}^{\dagger}$ & 4.6 & 6.3 \\
\hline Bulk density $\left(\mathrm{Mg} / \mathrm{m}^{3}\right) \dagger$ & 1.2 & 1.0 \\
\hline Organic C (\%)【 & 2.0 & 3.5 \\
\hline Total N (\%)\# & 0.15 & 0.39 \\
\hline $\mathrm{C}: \mathrm{N}$ & 13.4 & 9.0 \\
\hline
\end{tabular}

† Holmes and Zak (1994).

$¥$ Zak and Pregitzer (1990).

\& MacDonald et al. (1992).

$\|$ Merrill (1991).

II Toland and Zak (1994).

\# W. E. Holmes, unpublished data.

randomly located within each stand. Two of the four plots in each stand were randomly selected for clearcut harvest, providing four replicates of clear-cut and control (i.e., intact) treatments in each ecosystem. A buffer strip surrounding the clear-cut plots $(22.5 \mathrm{~m}$ wide) was established, bringing the total harvested area to 0.375 ha $(50 \times 75 \mathrm{~m})$. In order to minimize rooting of adjacent trees into the clear-cut plots, a trench 0.25 $\mathrm{m}$ wide and $1.3 \mathrm{~m}$ deep was excavated $15 \mathrm{~m}$ from the perimeter of each clear-cut plot following litterfall in October 1991. Trees $>10 \mathrm{~cm}$ dbh were harvested in December 1991. Stems were cut into 2.5-m lengths and carried off-site with a rubber-tired logging vehicle. Branches and cut stems $<10 \mathrm{~cm}$ dbh were distributed throughout the clear-cut areas. We monitored soil $\mathrm{N}$ transformations and losses in intact and clear-cut plots for one year following harvest (1992).

\section{$N$ leaching}

Leaching of ammonium $\left(\mathrm{NH}_{4}^{+}\right)$and nitrate $\left(\mathrm{NO}_{3}{ }^{-}\right)$ was determined by lysimetry. Four ceramic-cup lysimeters were installed in November 1989 at 10-m intervals along the long axis of each plot. All lysimeters were placed to collect water at a depth of $1 \mathrm{~m}$ below the soil surface, well beneath the majority of fine roots in these ecosystems (Gale and Grigal 1987). Water samples were collected monthly from May to November 1992. A tension of $35 \mathrm{kPa}$ was reapplied to lysimeters on each collection date. Concentrations of $\mathrm{NH}_{4}{ }^{+}-\mathrm{N}$ and $\mathrm{NO}_{3}{ }^{-} \mathrm{N}$ in soil water were determined using an Alpkem RFA 300 Rapid Flow Analyzer (Astoria-Pacific International, Clackamas, Oregon, USA).

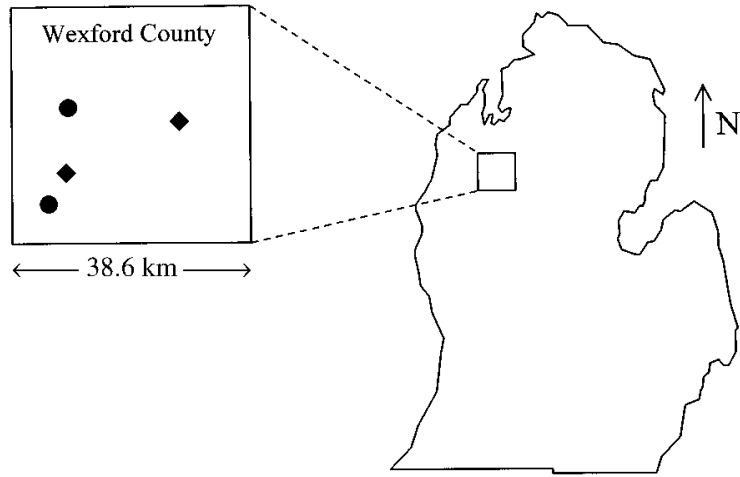

FIG. 1. Location of study sites in Wexford County, northern Lower Michigan, United States: two sugar maple-red oak-Maianthemum stands ( ) and two sugar maple-basswood-Osmorhiza stands ().

Monthly mean concentrations were converted to areal $\mathrm{N}$ leaching losses (grams of $\mathrm{N}$ per square meter) using a water budget method (Thornthwaite and Mather 1957). This approach uses mean monthly temperature and precipitation to predict potential evapotranspiration (PET), which is then used in conjunction with soil available water content to estimate actual evapotranspiration (AET) and water yield. In the clear-cut plots, a $29 \%$ increase in annual water yield in the year following harvest was assumed, based on observations in four clear-cut watersheds in the eastern United States (Verry 1987, Hornbeck et al. 1993). Monthly water yields in the clear-cut plots were estimated by reducing PET values to $45 \%$, which resulted in a $29 \%$ increase in annual water yield.

\section{Denitrification}

Biological loss of $\mathrm{N}$ through denitrification was measured using acetylene inhibition with static soil cores (Tiedje et al. 1989). Soil samples were collected at 4wk intervals through the 1992 growing season (MayNovember) from three or four sampling points positioned every $10 \mathrm{~m}$ along the long axis of each $5 \times 30$ $\mathrm{m}$ plot. Soil samples were taken to a depth of $10 \mathrm{~cm}$ after removing the loose litter $\left(\mathrm{O}_{\mathrm{i}}\right)$. In the sugar maplebasswood ecosystem, soils were collected from the surface of the A horizon; in the sugar maple-red oak ecosystem, soil samples included a thin layer of $\mathrm{O}_{\mathrm{a}}$ horizon $(<1.5 \mathrm{~cm})$ above the A horizon. Cores were collected in $20-\mathrm{cm}$ acrylic tubes $(2.5 \mathrm{~cm}$ diameter), which were sealed at both ends with rubber septa and stored on ice until processing within $36 \mathrm{~h}$ of collection. Soil temperature $(5 \mathrm{~cm}$ depth) was measured with a digital thermometer. In the lab, cores were unsealed and brought to room temperature for $2 \mathrm{~h}$, the septa were replaced, and pressure within the cores was released by inserting a needle. Acetylene was added to each sample to yield a partial pressure of $\sim 15 \mathrm{kPa}$; the atmosphere was thoroughly mixed by pumping a $60-\mathrm{mL}$ syringe six times. At 3 and $6 \mathrm{~h}$ following addition of acetylene, 3.5-mL 
gas samples were transferred to 3-mL evacuated Venoject vials (Terumo Corporation, Elkton, Maryland, USA). Gas samples were subsequently analyzed for $\mathrm{N}_{2} \mathrm{O}$ using a Tracor 540 gas chromatograph with a ${ }^{63} \mathrm{Ni}$ electron-capture detector (Tracor, Austin, Texas, USA) and a Porapak Q column (Supelco, Bellefonte, Pennsylvania, USA).

The headspace volume of each core was measured using a pressure transducer (Parkin et al. 1984). Moisture content of each soil sample was determined gravimetrically following the assay, and soil water $\mathrm{N}_{2} \mathrm{O}$ concentrations were calculated using a Bunson coefficient of 0.544 (Tiedje 1982). Denitrification rate was corrected to field temperature using a $\mathrm{Q}_{10}$ of 2 (Rolston et al. 1984, Tiedje et al. 1989) and converted to an areal basis $\left(\mathrm{mg} \mathrm{N} \mathrm{N}_{2} \mathrm{O}-\mathrm{N} \cdot \mathrm{m}^{-2} \cdot \mathrm{d}^{-1}\right)$ using soil bulk density. We assumed that the denitrification rate measured on each sampling date was representative of the previous 4-wk period. Annual denitrification rates $\left(\mathrm{g} \mathrm{N}_{2} \mathrm{O}-\mathrm{N} \cdot \mathrm{m}^{-2} \cdot \mathrm{yr}^{-1}\right)$ were calculated by summing daily rates over the eight sampling dates; we assumed that denitrification was minimal during the winter months.

\section{Net $N$ mineralization and nitrification}

Net $\mathrm{N}$ mineralization and nitrification were measured using an in situ buried bag technique (Eno 1960). At each sampling point where denitrification cores were collected, a pair of soil cores $(5.2 \mathrm{~cm}$ diameter) was collected to a depth of $10 \mathrm{~cm}$ beneath the $\mathrm{O}_{i}$ horizon, as described for denitrification samples. One core was placed intact into a polyethylene bag, sealed, and returned to its original position, covered with leaves, to incubate for $4 \mathrm{wk}$. The second soil core was sealed in a polyethylene bag, stored on ice, transported to the laboratory, and processed within $24 \mathrm{~h}$ of collection. Roots and material $>2 \mathrm{~mm}$ were removed, and the contents of each polyethylene bag were homogenized by hand. Portions of fresh soil samples were used to determine gross $\mathrm{N}$ transformation rates and microbial biomass. A 10-g subsample from each bag was ovendried for $24 \mathrm{~h}$ at $105^{\circ} \mathrm{C}$ to determine soil moisture content. A second 10-g subsample was extracted with 20 $\mathrm{mL} 2 \mathrm{~mol} / \mathrm{L} \mathrm{KCl}$. All extracts were shaken $30 \mathrm{~min}$ on an orbital shaker, filtered through pre-rinsed Whatman number 42 filter paper, and analyzed for $\mathrm{NH}_{4}{ }^{+}-\mathrm{N}$ and $\mathrm{NO}_{3}{ }^{-}-\mathrm{N}$ using an Alpkem RFA 300 Rapid Flow Analyzer. After retrieval the following month, the incubated soil cores were analyzed for $\mathrm{NH}_{4}{ }^{+} \mathrm{N}$ and $\mathrm{NO}_{3}{ }^{-}$ $\mathrm{N}$ in the same manner. Net $\mathrm{N}$ mineralization was calculated from the increase in $\mathrm{NH}_{4}{ }^{+}-\mathrm{N}$ and $\mathrm{NO}_{3}{ }^{-}-\mathrm{N}$ concentrations in excess of initial concentrations. Net nitrification was calculated from the increase of $\mathrm{NO}_{3}{ }^{-}-\mathrm{N}$ in incubated samples. Pools and rates were expressed on an areal basis using bulk density.

\section{Microbial biomass $C$ and $N$}

Microbial biomass $\mathrm{C}$ and $\mathrm{N}$ were estimated using the chloroform fumigation-incubation method (Voroney and Paul 1984). A 20-g subsample from each fresh soil sample was fumigated for $18 \mathrm{~h}$ with ethanol-free chloroform in a vacuum dessicator. A second 20-g subsample was simultaneously incubated in a moist dessicator (no chloroform) to act as a control. After repeated vacuuming and aeration (eight volumes) to eliminate residual chloroform, each fumigated sample was inoculated with $0.5 \mathrm{~g}$ of soil from the paired, nonfumigated sample. Fumigated and nonfumigated samples were placed in 0.95-L Mason jars equipped with rubber septa for gas sampling and were incubated in the dark for 10 $\mathrm{d}$ at $22^{\circ} \mathrm{C}$. Headspace gas samples $(0.4 \mathrm{~mL})$ were analyzed for $\mathrm{CO}_{2}$ using a Tracor 540 gas chromatograph equipped with a Porapak $\mathrm{Q}$ column and a thermal conductivity detector. Following $\mathrm{CO}_{2}$ analysis, soils were extracted with $2 \mathrm{~mol} / \mathrm{L} \mathrm{KCl}$, and the filtrates were analyzed for $\mathrm{NH}_{4}{ }^{+}-\mathrm{N}$ and $\mathrm{NO}_{3}{ }^{-}-\mathrm{N}$ as previously described. Microbial $\mathrm{C}$ was calculated by dividing the flush of $\mathrm{CO}_{2}-\mathrm{C}$ from fumigated samples by 0.41 (Voroney and Paul 1984). Microbial $\mathrm{N}$ was calculated by dividing the flush of $\mathrm{N}$ (fumigated minus control) by a correction factor $\left(k_{n}\right)$, using the equation of Voroney and Paul (1984): $k_{n}=0.014\left(\mathrm{C}_{\mathrm{f}} / \mathrm{N}_{\mathrm{f}}\right)+0.39$, where $\mathrm{C}_{\mathrm{f}}$ and $\mathrm{N}_{\mathrm{f}}$ are the flushes of $\mathrm{C}$ and $\mathrm{N}$ from fumigated samples, respectively.

\section{Gross $N$ mineralization, immobilization, and nitrification}

Net rates of $\mathrm{N}$ mineralization and nitrification provide limited insight into microbial $\mathrm{N}$ transformations, because net rates result from opposing microbial processes, such as gross mineralization and immobilization of N (Davidson et al. 1992). In order to elucidate the microbial mechanisms regulating $\mathrm{N}$ transformation rates, we measured gross rates of $\mathrm{N}$ mineralization, $\mathrm{N}$ immobilization, and nitrification in field fresh soil using isotope dilution (Davidson et al. 1991, Hart et al. 1994). Subsamples from soil cores collected in April, June, August, and October 1992 were pooled by plot (four samples per plot) and mixed. Two 70-g samples were placed in 500-mL plastic beakers and covered with Parafilm. The $\mathrm{NH}_{4}{ }^{+}-\mathrm{N}$ pool of one sample and the $\mathrm{NO}_{3}{ }^{-}-\mathrm{N}$ pool of the paired sample were enriched to $\sim 5 \%{ }^{15} \mathrm{~N}$ using $3-\mathrm{mL}$ aliquots of $\left({ }^{15} \mathrm{NH}_{4}\right)_{2} \mathrm{SO}_{4}$ or $\mathrm{K}^{15} \mathrm{NO}_{3}$ solutions $\left(99 \%{ }^{15} \mathrm{~N}\right)$, respectively. The ${ }^{15} \mathrm{~N}$ solutions were pipetted evenly across the soil surface to avoid pooling. Soils were incubated at $25^{\circ} \mathrm{C}$, and after $5 \mathrm{~d}$, a 10-g subsample was extracted with $2 \mathrm{~mol} / \mathrm{L} \mathrm{KCl}$ and analyzed for $\mathrm{NH}_{4}{ }^{+} \mathrm{N}$ and $\mathrm{NO}_{3}{ }^{-}-\mathrm{N}$ as previously described. A $20-\mathrm{g}$ soil sample was dried $24 \mathrm{~h}$ at $105^{\circ} \mathrm{C}$ and pulverized using a roller mill in preparation for total $\mathrm{N}$ and ${ }^{15} \mathrm{~N}$ analysis. The microbial $\mathrm{C}$ and $\mathrm{N}$ of two 20 -g subsamples were determined by the chloroform fumigation-incubation method. The natural abundance of ${ }^{15} \mathrm{~N}$ was determined for each ecosystem by preparing composite soil samples, which were moistened, incubated, and extracted using the same methods as for the enriched samples. 
A diffusion procedure was used to separate $\mathrm{NH}_{4}{ }^{+}$and $\mathrm{NO}_{3}{ }^{-}$for ${ }^{15} \mathrm{~N}$ analysis (Brooks et al. 1989). We placed 20-mL aliquots of $\mathrm{KCl}$ extracts in plastic specimen containers. Where necessary, 5 or $10 \mathrm{~mL}$ of $5 \mathrm{mg} \mathrm{N} / \mathrm{mL}$ $\left({ }^{14} \mathrm{NH}_{4}\right)_{2} \mathrm{SO}_{4}$ or $\mathrm{K}^{14} \mathrm{NO}_{3}$ solution was added to raise the $\mathrm{N}$ content of samples above $50 \mathrm{mg} \mathrm{N}$, into the optimal detection range of the mass spectrometer. Cellulose fiber disks punched from Whatman number 3 filter paper were acidified with $10 \mathrm{~mL} 2.5 \mathrm{~mol} / \mathrm{L} \mathrm{KHSO}_{4}$, pierced with silver wire, and were suspended above the solution inside each sealed specimen container. Following a 6d diffusion with $\mathrm{MgO}$ to collect ${ }^{15} \mathrm{NH}_{4}{ }^{+}$, the disks were replaced and Devarda's alloy was added to the containers for a second 6-d diffusion to capture ${ }^{15} \mathrm{NO}_{3}{ }^{-}$. Dried disks were placed in tin capsules and analyzed for ${ }^{15} \mathrm{~N}$ abundance using a Europa Scientific Automated Nitrogen Carbon Analyzer (Europa Scientific, Franklin, Ohio, USA).

Gross rates of $\mathrm{N}$ mineralization, nitrification, and $\mathrm{N}$ consumption were calculated using the equations of Kirkham and Bartholomew (1954). Gross $\mathrm{NH}_{4}{ }^{+}-\mathrm{N}$ immobilization was calculated by subtracting the gross nitrification rate from the gross $\mathrm{NH}_{4}{ }^{+} \mathrm{N}$ consumption rate. Gross $\mathrm{NO}_{3}{ }^{-}-\mathrm{N}$ immobilization was assumed to be equivalent to gross $\mathrm{NO}_{3}{ }^{-}-\mathrm{N}$ consumption, because other $\mathrm{NO}_{3}{ }^{-}$-consuming processes (plant uptake, leaching, and denitrification) were minimal or absent during the laboratory incubation.

Mean residence time (MRT) of the microbial biomass $\mathrm{N}$ pool was calculated by dividing microbial biomass $\mathrm{N}$ by gross $\mathrm{N}$ immobilization rate, yielding residence time of $\mathrm{N}$ atoms in microbial biomass in units of days (Hart et al. 1994). Likewise, MRTs of soil $\mathrm{NH}_{4}{ }^{+}$and $\mathrm{NO}_{3}{ }^{-}$pools were calculated by dividing the pool size by gross $\mathrm{N}$ mineralization and nitrification rates, respectively.

\section{Statistical analyses}

Repeated-measures ANOVA was used to compare temporal changes in soil $\mathrm{NH}_{4}{ }^{+}$and $\mathrm{NO}_{3}{ }^{-}$pools, $\mathrm{N}$ transformation rates, $\mathrm{N}$ leaching, and microbial biomass $\mathrm{C}$ and $\mathrm{N}$ between ecosystems and between clear-cut and intact plots within ecosystems. Plot means were analyzed using a balanced partially nested, partially crossed repeated-measures ANOVA (Wilkinson 1990). Month was the trials factor, ecosystem and treatment were fixed factors, and stand was a random factor. Stands $(K=4)$ were nested within ecosystems $(I=2)$, which were crossed with treatment $(J=2$; Netter et al. 1990).

Mean annual rates of $\mathrm{N}$ transformations, annual leaching losses of $\mathrm{N}$, annual mean microbial $\mathrm{C}$ and $\mathrm{N}$, and ${ }^{15} \mathrm{~N}$ recovery were compared among ecosystems and treatments using a balanced three-way partially nested, partially crossed ANOVA with stands nested within ecosystem. All pairwise multiple comparisons were made with Tukey's HSD procedure using model MSE values. Annual mean rates of gross $\mathrm{N}$ mineraliza-
TABLE 2. Mean soil water content and temperature (0-10 $\mathrm{cm}$ depth) in intact and clear-cut plots within two hardwood ecosystems in northern Lower Michigan during the growing season in 1992, following winter harvest. Values are plot means, with standard deviations in parentheses $(n=$ 4).

\begin{tabular}{ccc}
\hline $\begin{array}{c}\text { Plot } \\
\text { treatment }\end{array}$ & $\begin{array}{c}\text { Soil water, } \theta \\
\left(\mathrm{cm}^{3} / \mathrm{cm}^{3}\right)\end{array}$ & $\begin{array}{c}\text { Soil temperature } \\
\left({ }^{\circ} \mathrm{C}\right)\end{array}$ \\
\hline Intact & $0.16^{\mathrm{a}}$ & $10.6^{\mathrm{a}}$ \\
& $(0.037)$ & $(0.42)$ \\
Clear-cut & $0.20^{\mathrm{b}}$ & $12.7^{\mathrm{b}}$ \\
& $(0.027)$ & $(1.07)$ \\
\hline
\end{tabular}

Note: Means in a column followed by the same letter do not differ significantly.

tion, nitrification, and $\mathrm{NH}_{4}{ }^{+}$and $\mathrm{NO}_{3}{ }^{-}$immobilization were compared between intact and clear-cut plots using a two-sample $t$ test (separate variances). Statistical results were accepted as significant at $\alpha=0.05$.

The assumption of normality was tested using skewness and kurtosis. Homogeneity of group variances was tested using a combination of Bartlett's test and plots of residuals vs. predicted values. The harvesting treatment greatly increased the variance of most processes, causing significant departures from homogeneity, which were not improved by various transformations applied to the data; thus, statistical results were based on untransformed data.

\section{RESULTS}

\section{Physical site conditions and vegetation growth}

Soil water content and temperature were significantly greater in the clear-cut plots within each ecosystem (Table 2). The greatest differences in soil moisture were observed in the sugar maple-red oak ecosystem, where clear-cut plots had twice the soil moisture of intact plots ( 0.17 vs. $\left.0.08 \mathrm{~cm}^{3} / \mathrm{cm}^{3}\right)$ from May to August. During the same period, soil temperature in clear-cut plots averaged $3.6^{\circ} \mathrm{C}$ warmer than intact plots in both ecosystems.

Vegetation regrowth during the first season following harvest varied among the clear-cut plots and included a patchy mixture of stump sprouts, growth of some native herbaceous species, and colonization by nonnative herbaceous species (e.g., Verbascum thapsis). Generally, herbaceous growth dominated the plant cover in the sugar maple-basswood ecosystem, whereas plant cover in the sugar maple-red oak ecosystem was limited to resprouting of cut trees. Numerous sugar maple and basswood stumps resprouted, but foliage was repeatedly browsed by white-tailed deer. In the sugar maple-red oak clear-cuts, oak resprouting was not observed, but some beech (Fagus sylvatica Ehrh.) stumps and the majority of black cherry (Prunus serotina Ehrh.) stumps successfully resprouted and were not browsed by white-tailed deer. 
TABLE 3. Annual rates of $\mathrm{N}$ leaching and denitrification in intact and clear-cut plots of two hardwood ecosystems. Values, in grams of $\mathrm{N}$ per square meter per year, are plot means with standard deviations in parentheses $(n=4)$.

\begin{tabular}{clccc}
\hline \hline Ecosystem & Treatment & $\begin{array}{c}\mathrm{NH}_{4}^{+} \\
\text {leaching }\end{array}$ & $\begin{array}{c}\mathrm{NO}_{3}^{-} \\
\text {leaching }\end{array}$ & $\begin{array}{c}\text { Denitrifi- } \\
\text { cation }\end{array}$ \\
\hline $\begin{array}{l}\text { Sugar maple- } \\
\text { red oak }\end{array}$ & Intact & $0.05^{\mathrm{a}}$ & $0.15^{\mathrm{a}}$ & $0.08^{\mathrm{a}}$ \\
& Clear-cut & $0.08^{\mathrm{a}}$ & $5.03^{\mathrm{b}}$ & $0.16^{\mathrm{a}}$ \\
& & $(0.083)$ & $(2.205)$ & $(0.106)$ \\
Sugar maple- & Intact & $0.06^{\mathrm{a}}$ & $0.23^{\mathrm{a}}$ & $0.42^{\mathrm{a}}$ \\
basswood & & $(0.060)$ & $(0.186)$ & $(0.374)$ \\
& Clear-cut & $0.01^{\mathrm{a}}$ & $4.69^{\mathrm{b}}$ & $0.29^{\mathrm{a}}$ \\
& & $(0.010)$ & $(4.088)$ & $(0.264)$ \\
\hline
\end{tabular}

Note: Means in a column followed by the same letter are not significantly different.

\section{Leaching losses of nitrogen}

Clear-cutting led to significant loss of $\mathrm{N}$ through $\mathrm{NO}_{3}{ }^{-}$leaching in both ecosystems, which averaged $4.9 \mathrm{~g} \mathrm{~N} \cdot \mathrm{m}^{-2} \cdot \mathrm{yr}^{-1}$ in clear-cut plots and $0.2 \mathrm{~g} \mathrm{~N} \cdot \mathrm{m}^{-2} \cdot \mathrm{yr}^{-1}$ in intact plots (Table 3). Annual rates of $\mathrm{NH}_{4}{ }^{+}$leaching were low and did not differ between clear-cut and intact plots (Table 3). Loss of $\mathrm{N}$ through $\mathrm{NO}_{3}{ }^{-}$leaching varied significantly through time (e.g., monthly). The concentration of $\mathrm{NO}_{3}{ }^{-}$in water collected from lysimeters increased from $<1 \mathrm{mg} \mathrm{N} / \mathrm{L}$ in June to $15 \mathrm{mg} \mathrm{N} / \mathrm{L}$ in October in clear-cut plots, but remained $<2 \mathrm{mg}$ N/L throughout the year in intact plots (Fig. 2A). Clear-cut plots of both ecosystems lost $2.4 \mathrm{~g} \mathrm{NO}_{3}{ }^{-} \mathrm{N} / \mathrm{m}^{2}$ in October (Fig. 2B), accounting for half of the annual $\mathrm{NO}_{3}{ }^{-}$leaching losses (Table 3).

\section{Denitrification}

Annual rates of denitrification ranged from 0.06 to $0.65 \mathrm{~g} \mathrm{~N} \cdot \mathrm{m}^{-2} \cdot \mathrm{yr}^{-1}$ among plots $(n=16)$ within both ecosystems, and did not differ significantly between clear-cut and intact treatments (Table 3). Averaged across treatments, annual denitrification rates were significantly greater in the sugar maple-basswood ecosystem than in the sugar maple-red oak ecosystem ( 0.35 vs. $0.12 \mathrm{~g} \mathrm{~N} \cdot \mathrm{m}^{-2} \cdot \mathrm{yr}^{-1}$, respectively; $\left.n=8\right)$. Daily rates of denitrification ranged from 0.02 to $11.2 \mathrm{mg}$ $\mathrm{N} \cdot \mathrm{m}^{-2} \cdot \mathrm{d}^{-1}$, with greatest rates measured in April and September (Fig. 3). In April, four out of 12 samples had rates $>20 \mathrm{mg} \mathrm{N} \cdot \mathrm{m}^{-2} \cdot \mathrm{d}^{-1}$ in intact plots of the sugar maple-basswood ecosystem. Variability was higher within intact plots $(\mathrm{CV}=89 \%)$ than in clear-cut plots $(\mathrm{CV}=44 \%)$.

\section{Net nitrogen mineralization and nitrification}

Annual rates of net $\mathrm{N}$ mineralization and nitrification were significantly greater in intact sugar maple-basswood plots than in intact plots of the sugar maple-red oak ecosystem. Clear-cut harvest significantly increased annual net $\mathrm{N}$ mineralization and nitrification in both ecosystems, and rates became equivalent (Table 4). Annual net $\mathrm{N}$ mineralization in the sugar maple-

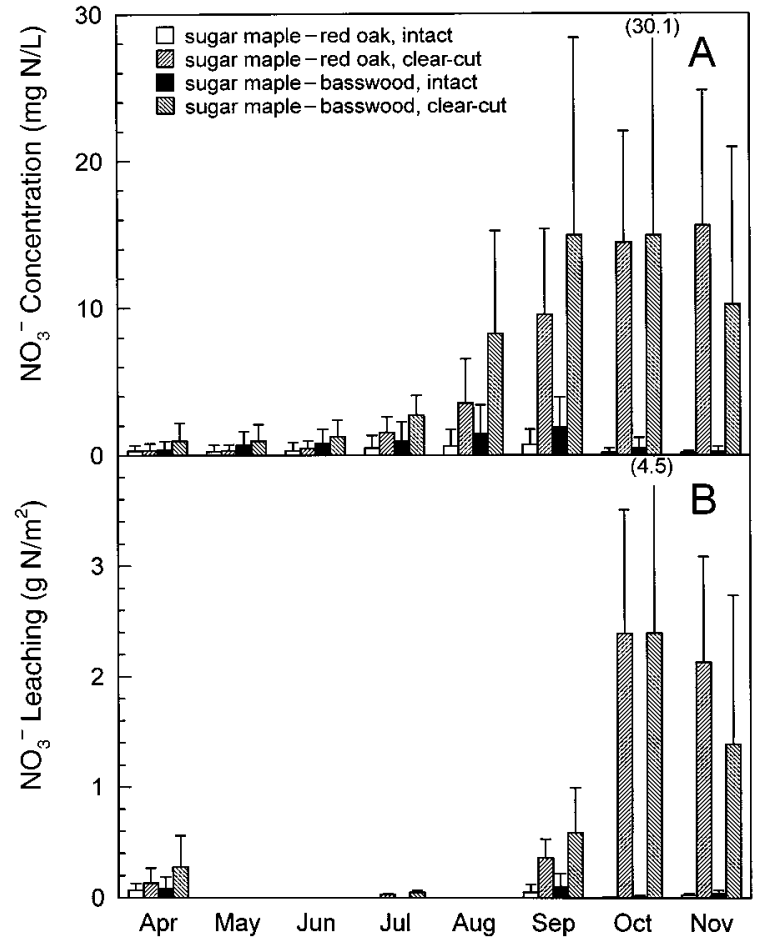

FIG. 2. Lysimeter $\mathrm{NO}_{3}{ }^{-}$concentrations (A) and monthly rates of $\mathrm{NO}_{3}{ }^{-}$leaching (B) in clear-cut and intact plots of two northern hardwood ecosystems in northern Lower Michigan following winter harvest. Values are means $+1 \mathrm{SD}(n=4)$.

red oak ecosystem increased threefold and net nitrification increased by a factor of four in the clear-cut plots (relative to intact plots). In the sugar maple-basswood ecosystem, net $\mathrm{N}$ mineralization and nitrification increased $45 \%$ and $52 \%$, respectively, in clear-cut plots. On an annual basis, nearly all $(>90 \%) \mathrm{NH}_{4}{ }^{+}$produced in the sugar maple-basswood ecosystem was oxidized to $\mathrm{NO}_{3}{ }^{-}$, whereas annual net nitrification was about half (41-64\%) of annual net $\mathrm{N}$ mineralization in the sugar maple-red oak ecosystem. These relationships were not significantly altered by clear-cutting in either ecosys-

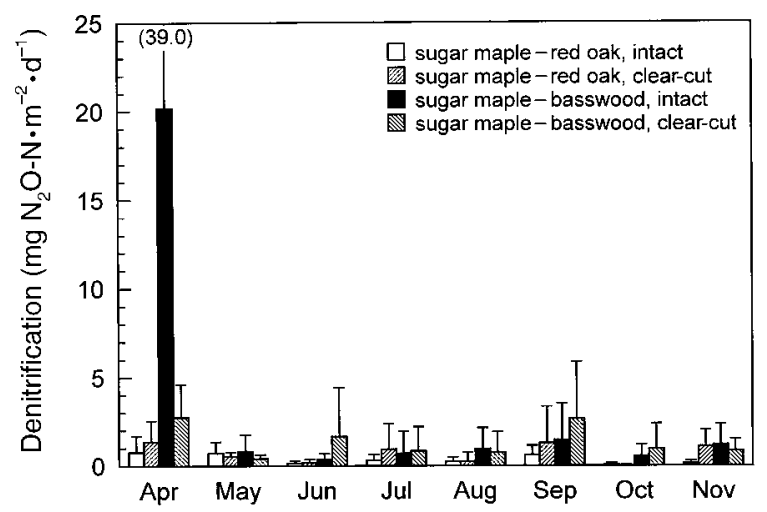

FIG. 3. Denitrification rates in clear-cut and intact plots in stands of two northern hardwood ecosystems. Values are means $+1 \mathrm{SD}(n=4)$. 
TABLE 4. Mean annual rates of net $\mathrm{N}$ mineralization and nitrification and percentages of $\mathrm{N}$ nitrified (net nitrification as a percentage of net $\mathrm{N}$ mineralization) in intact and clearcut plots within two hardwood ecosystems. Values are plot means, with standard deviations in parentheses $(n=4)$.

\begin{tabular}{|c|c|c|c|c|}
\hline Ecosystem & Treatment & $\begin{array}{c}\text { Net N } \\
\text { minerali- } \\
\text { zation } \\
\left(\mathrm{g} \cdot \mathrm{m}^{-2} \cdot \mathrm{yr}^{-1}\right)\end{array}$ & $\begin{array}{c}\text { Net N } \\
\text { nitrifi- } \\
\text { cation } \\
\left(\mathrm{g} \cdot \mathrm{m}^{-2} \cdot \mathrm{yr}^{-1}\right)\end{array}$ & $\begin{array}{c}\text { Percent- } \\
\text { age of } N \\
\text { nitrified }\end{array}$ \\
\hline \multirow[t]{2}{*}{$\begin{array}{l}\text { Sugar maple- } \\
\text { red oak }\end{array}$} & Intact & $\begin{array}{c}5.1^{\mathrm{a}} \\
(1.35)\end{array}$ & $\begin{array}{c}2.3^{\mathrm{a}} \\
(1.56)\end{array}$ & $\begin{array}{c}41^{\mathrm{a}} \\
(21.6)\end{array}$ \\
\hline & Clear-cut & $\begin{array}{l}14.7^{\mathrm{c}} \\
(1.22)\end{array}$ & $\begin{array}{r}9.6^{\mathrm{bc}} \\
(3.64)\end{array}$ & $\begin{array}{c}64^{\mathrm{a}} \\
(19.9)\end{array}$ \\
\hline \multirow[t]{2}{*}{$\begin{array}{c}\text { Sugar maple- } \\
\text { basswood }\end{array}$} & Intact & $\begin{array}{c}9.5^{\mathrm{b}} \\
(2.88)\end{array}$ & $\begin{array}{l}8.7^{\mathrm{b}} \\
(3.14)\end{array}$ & $\begin{array}{l}90^{\mathrm{b}} \\
(6.7)\end{array}$ \\
\hline & Clear-cut & $\begin{array}{l}13.7^{\mathrm{c}} \\
(2.30)\end{array}$ & $\begin{array}{l}13.2^{\mathrm{c}} \\
(1.90)\end{array}$ & $\begin{array}{l}97^{\mathrm{b}} \\
(3.1)\end{array}$ \\
\hline
\end{tabular}

Note: Means in a column followed by the same letter do not differ significantly.

tem. However, in the sugar maple-red oak ecosystem, net nitrification increased consistently through the growing season from 27\% (April) to $88 \%$ (November) of net $\mathrm{N}$ mineralization. Annual net nitrification rates were similar among clear-cut plots of both ecosystems (Table 4).

Net $\mathrm{N}$ mineralization and nitrification varied significantly through the growing season. During April and May, rates of net $\mathrm{N}$ mineralization and nitrification were comparable among clear-cut and intact plots in both ecosystems (Fig. 4). From June to November, net $\mathrm{N}$ mineralization and nitrification rates in the sugar maple-basswood ecosystem were $>50 \%$ higher in clear-cut plots, relative to rates measured in intact plots. Differences were even more pronounced in the sugar maple-red oak ecosystem, where rates of net $\mathrm{N}$ mineralization exhibited a twofold increase and nitrification exhibited a 3.5-fold increase in clear-cut plots during the same period.

Seasonal patterns of net $\mathrm{N}$ mineralization in clearcut plots were similar between ecosystems; maximum rates averaged $102 \mathrm{mg} \mathrm{N} \cdot \mathrm{m}^{-2} \cdot \mathrm{d}^{-1}$ during August (Fig. 4A). In the sugar maple-basswood ecosystem, net nitrification rates closely matched net $\mathrm{N}$ mineralization rates through the growing season (Fig. 4). In the sugar maple-red oak ecosystem, net nitrification rates were consistently low $\left(\sim 10 \mathrm{mg} \mathrm{N} \cdot \mathrm{m}^{-2} \cdot \mathrm{d}^{-1}\right)$ in the intact plots; in the clear-cut plots, nitrification rates increased from $18 \mathrm{mg} \mathrm{N} \cdot \mathrm{m}^{-2} \cdot \mathrm{d}^{-1}$ in June to $73 \mathrm{mg} \mathrm{N} \cdot \mathrm{m}^{-2} \cdot \mathrm{d}^{-1}$ in August, approaching the maximum rates in the clearcut plots of the sugar maple-basswood ecosystem (95 $\mathrm{mg} \mathrm{N} \cdot \mathrm{m}^{-2} \cdot \mathrm{d}^{-1}$; Fig. 4B).

The result of accelerated soil $\mathrm{N}$ transformation and diminished plant uptake is apparent in the changes in extractable $\mathrm{NH}_{4}{ }^{+}$and $\mathrm{NO}_{3}{ }^{-}$pools beginning in June (Fig. 5). In the sugar maple-red oak ecosystem, both $\mathrm{NH}_{4}{ }^{+}$and $\mathrm{NO}_{3}{ }^{-}$pools were both greatly elevated in clear-cut plots (1300 mg $\mathrm{NH}_{4}{ }^{+}-\mathrm{N} / \mathrm{m}^{2}$ and $636 \mathrm{mg}$ $\left.\mathrm{NO}_{3}{ }^{-}-\mathrm{N} / \mathrm{m}^{2}\right)$, relative to intact plots $\left(188 \mathrm{mg} \mathrm{NH}_{4}{ }^{+}-\mathrm{N} / \mathrm{m}^{2}\right.$

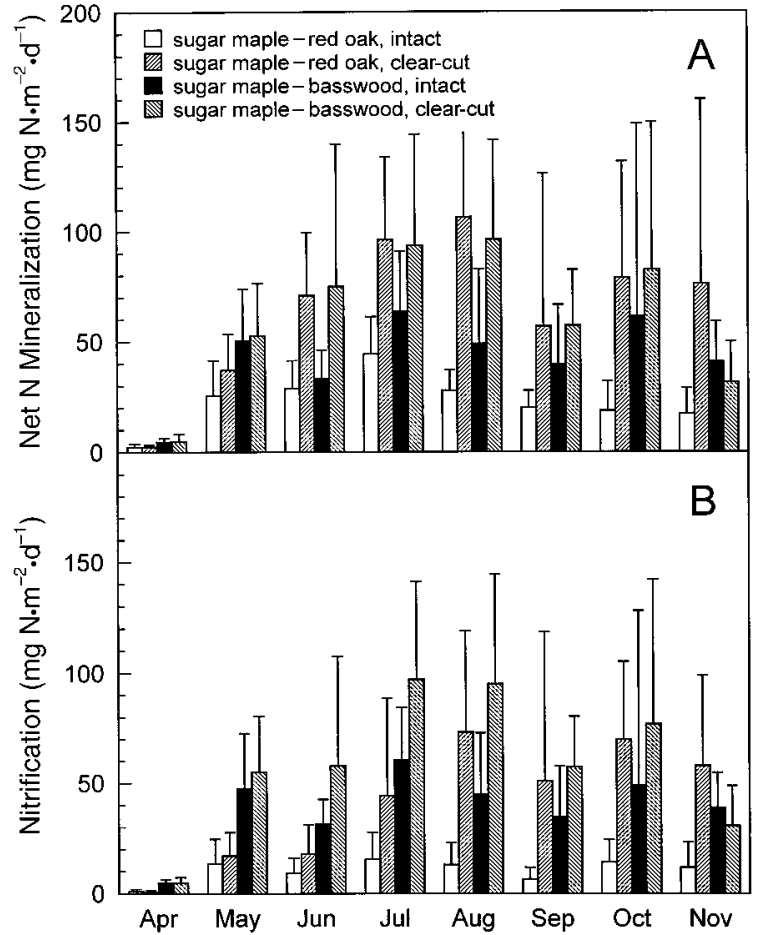

FIG. 4. Net $\mathrm{N}$ mineralization (A) and nitrification (B) rates within clear-cut and intact plots of two northern hardwood ecosystems. Values are means $+1 \mathrm{SD}(n=4)$.

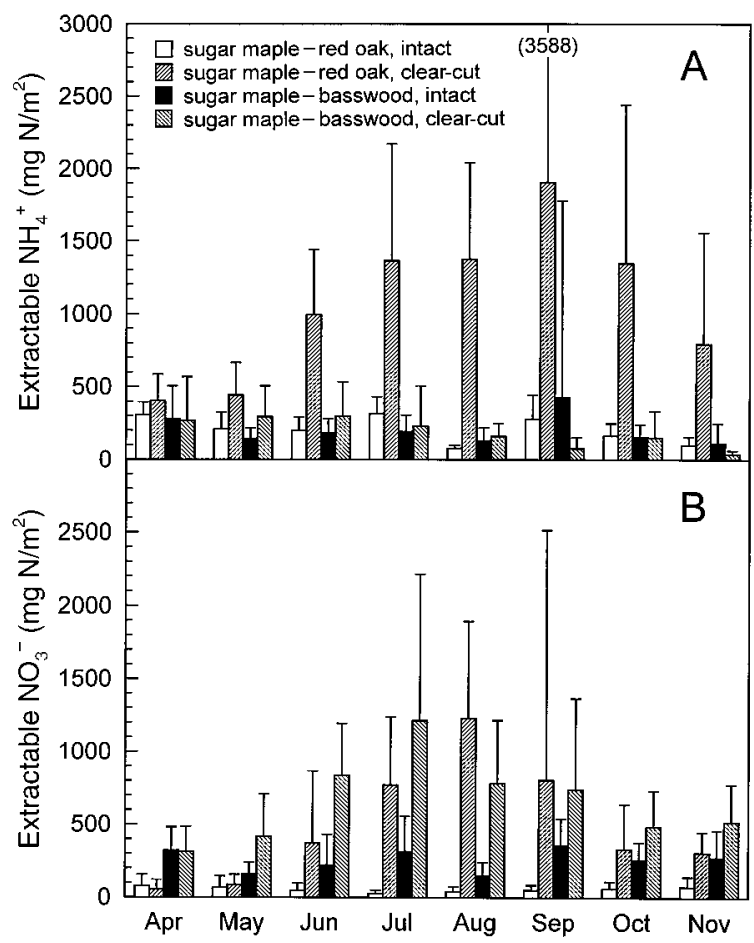

FIG. 5. Soil $\mathrm{NH}_{4}{ }^{+}$(A) and $\mathrm{NO}_{3}{ }^{-}$(B) pools within clearcut and intact plots of two hardwood ecosystems. Values are means $+1 \mathrm{SD}(n=4)$. 
TABLE 5. Annual mean pools of microbial biomass $\mathrm{C}$ and $\mathrm{N}$ (both in $\mathrm{g} / \mathrm{m}^{2}$ ) in intact and clear-cut plots within two northern hardwood ecosystems. Values are means, with standard deviations in parentheses $(n=4)$.

\begin{tabular}{llcc}
\hline \hline Ecosystem & Treatment & $\begin{array}{c}\text { Microbial } \\
\text { biomass C }\end{array}$ & $\begin{array}{c}\text { Microbial } \\
\text { biomass N }\end{array}$ \\
\hline $\begin{array}{l}\text { Sugar maple- } \\
\text { red oak }\end{array}$ & Intact & $73.5^{\mathrm{a}}$ & $11.1^{\mathrm{a}}$ \\
& & $(23.17)$ & $(4.12)$ \\
& Clear-cut & $96.5^{\mathrm{a}}$ & $13.5^{\mathrm{a}}$ \\
& & $(27.45)$ & $(4.56)$ \\
Sugar maple- & Intact & $144.8^{\mathrm{b}}$ & $22.7^{\mathrm{b}}$ \\
basswood & & $(62.42)$ & $(9.96)$ \\
& Clear-cut & $131.6^{\mathrm{b}}$ & $19.8^{\mathrm{b}}$ \\
& & $(51.82)$ & $(7.47)$ \\
\hline
\end{tabular}

Note: Means in a column followed by the same letter do not differ significantly.

and $50 \mathrm{mg} \mathrm{NO}{ }^{-}{ }^{-} \mathrm{N} / \mathrm{m}^{2}$ ). In the sugar maple-basswood ecosystem, the $\mathrm{NO}_{3}^{-}$pool was elevated $(763 \mathrm{mg}$ $\mathrm{NO}_{3}{ }^{-}-\mathrm{N} / \mathrm{m}^{2}$ in clear-cut plots vs. $261 \mathrm{mg} \mathrm{NO}{ }_{3}^{-}-\mathrm{N} / \mathrm{m}^{2}$ in intact plots), whereas the $\mathrm{NH}_{4}^{+}$pool was not significantly affected by clear-cutting (combined clear-cut and intact mean $\left.=178 \mathrm{mg} \mathrm{NH}_{4}{ }^{+}-\mathrm{N} / \mathrm{m}^{2}\right)$.

\section{Microbial biomass}

Annual mean microbial $\mathrm{C}$ and $\mathrm{N}$ pools were $>50 \%$ larger in the sugar maple-basswood ecosystem than in the sugar maple-red oak ecosystem, regardless of harvesting treatment (Table 5). Microbial $\mathrm{C}$ and $\mathrm{N}$ did not vary significantly through the growing season (data not shown) or among treatments (Table 5). Variability was consistently high within both clear-cut and intact plots (CV range 28-44\%). Microbial C:N ranged from 6.5 to 7.7 among all plots and did not differ significantly between clear-cut and intact plots. Pools of microbial C and $\mathrm{N}$ measured in ${ }^{15} \mathrm{~N}$ incubations did not differ from those measured in freshly collected soil samples ( $t$ test).

\section{Gross nitrogen mineralization, immobilization, and nitrification}

Recovery of added ${ }^{15} \mathrm{~N}$ from 5-d laboratory incubations averaged $69 \pm 2.5 \%$ (mean $\pm 1 \mathrm{SE}$ ), and did not differ significantly among treatments $(n=109, P$ $=0.657$ ). Mean daily rates of gross $\mathrm{N}$ mineralization and nitrification were substantially greater in clear-cut vs. intact plots during the summer months (Fig. 6). Gross rates of $\mathrm{NH}_{4}^{+}$and $\mathrm{NO}_{3}{ }^{-}$immobilization displayed a similar seasonal trend (Fig. 7). The effects of clear-cutting became apparent in June: in the sugar maple-basswood ecosystem, gross $\mathrm{N}$ mineralization, nitrification, and $\mathrm{NO}_{3}{ }^{-}$immobilization rates in the clearcut plots were twice those of the intact plots. In the sugar maple-red oak ecosystem, gross $\mathrm{N}$ mineralization and both $\mathrm{NH}_{4}{ }^{+}$and $\mathrm{NO}_{3}{ }^{-}$immobilization rates doubled in the clear-cut plots.

In August, $\mathrm{NO}_{3}{ }^{-}$transformations became more important in the clear-cut plots of the sugar maple-red oak ecosystem. Gross nitrification increased to $200 \mathrm{mg}$ $\mathrm{N} \cdot \mathrm{m}^{-2} \cdot \mathrm{d}^{-1}$ in clear-cut plots compared to $36 \mathrm{mg}$

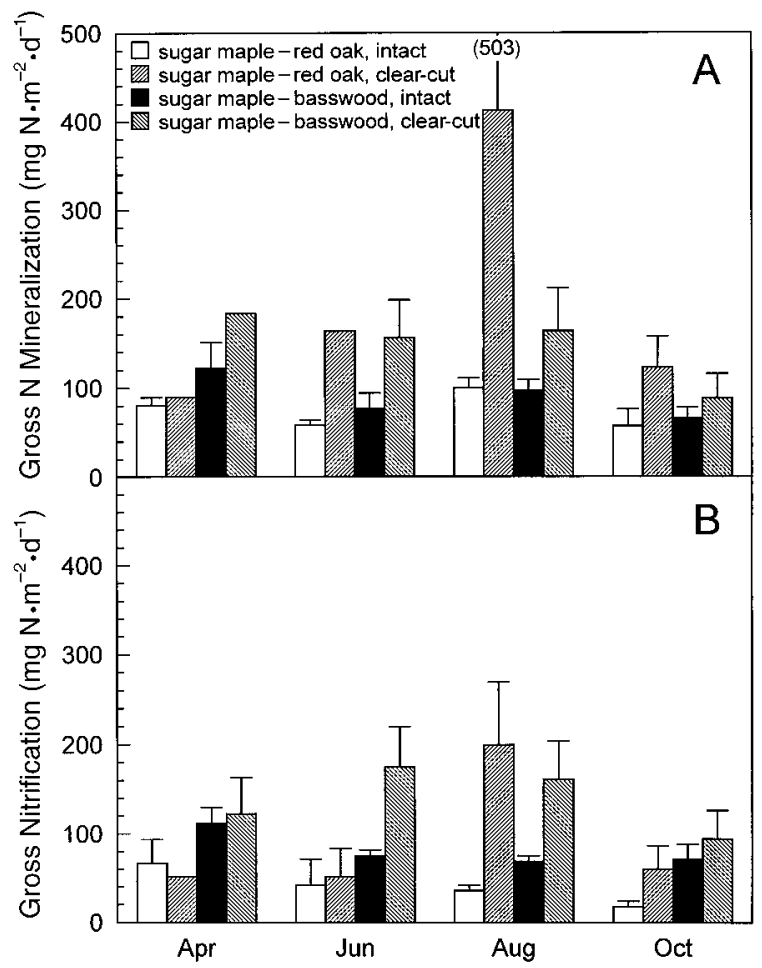

FIG. 6. Gross rates of $\mathrm{N}$ mineralization (A) and nitrification (B) within clear-cut and intact plots of two hardwood ecosystems. Values are means $+1 \mathrm{SD}(n=4)$.

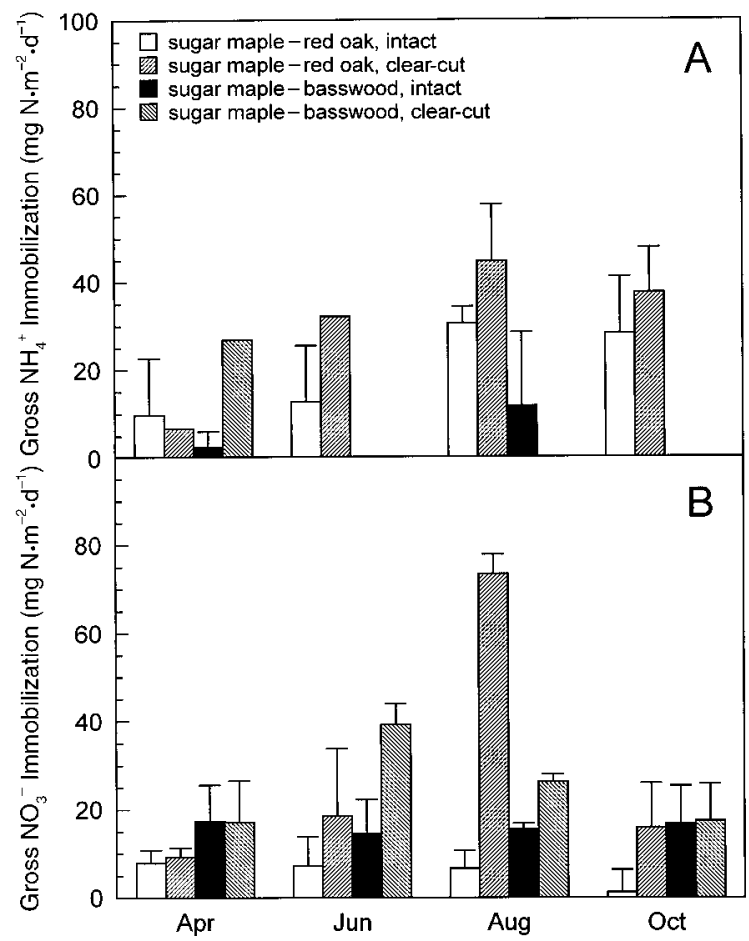

FIG. 7. Immobilization of $\mathrm{NH}_{4}{ }^{+}$(A) and $\mathrm{NO}_{3}{ }^{-}$(B) within clear-cut and intact plots of two hardwood ecosystems. Values are means $+1 \mathrm{SD}(n=4)$. 


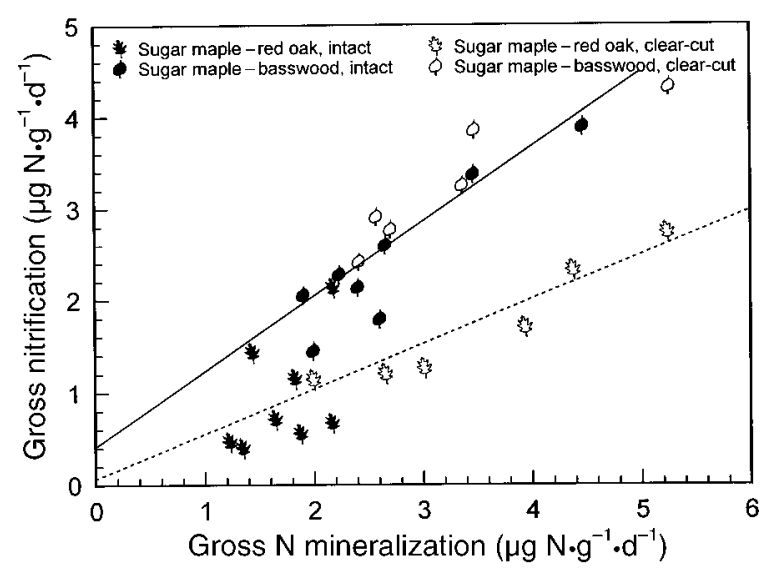

FIG. 8. The relationship between gross rates of $\mathrm{N}$ mineralization and nitrification measured in 5-d laboratory incubations of soil from two northern hardwood ecosystems The regression equations for each ecosystem are GNIT $=$ $0.485($ GMIN $)+0.068\left(R^{2}=0.67, P<0.001, n=14\right)$ for sugar maple-red oak (dashed line) and GNIT $=0.814($ GMIN) $+0.413\left(R^{2}=0.81, P<0.001, n=15\right)$ for sugar maplebasswood (solid line), where GNIT is gross nitrification, and GMIN is gross $\mathrm{N}$ mineralization in $\mu \mathrm{g} \mathrm{N} \cdot \mathrm{g}^{-1} \cdot \mathrm{d}^{-1}$. The data points represent observations in intact (solid leaves) and clear-cut (open leaves) plots within each ecosystem at four sampling dates during the growing season.

$\mathrm{N} \cdot \mathrm{m}^{-2} \cdot \mathrm{d}^{-1}$ in the intact plots (Fig. 6). At the same time, $\mathrm{NO}_{3}{ }^{-}$immobilization increased by an order of magnitude to $74 \mathrm{mg} \mathrm{N} \cdot \mathrm{m}^{-2} \cdot \mathrm{d}^{-1}$ in clear-cut plots relative to intact plots (Fig. 7), exceeding $\mathrm{NH}_{4}{ }^{+}$immobilization. Both gross $\mathrm{N}$ mineralization and $\mathrm{N}$ immobilization doubled from June to August in the clear-cut plots of the sugar maple-red oak ecosystem, resulting in the highest rates observed in either ecosystem.

Gross rates of $\mathrm{N}$ mineralization and nitrification (measured bimonthly) displayed a seasonal pattern comparable to field-measured net rates (Figs. 4 and 6). In fact, there was a positive linear relationship between field-measured rates of net $\mathrm{N}$ mineralization (in situ buried bags) and those rates measured in the laboratory using ${ }^{15} \mathrm{~N}$ dilution $\left(\mathrm{FMIN}=0.668(\mathrm{LMIN})+2.08, r^{2}\right.$ $=0.67, P<0.001, n=24$, where FMIN and LMIN are field and laboratory rates of net $\mathrm{N}$ mineralization, in milligrams of $\mathrm{N}$ per square meter per day, respectively). Generally, rates in laboratory incubations were $45 \%$ greater than field-measured rates.

Clear-cutting had no significant effect on the proportion of mineralized $\mathrm{N}$ oxidized to $\mathrm{NO}_{3}{ }^{-}$in either ecosystem. The proportion of mineralized $\mathrm{N}$ oxidized to $\mathrm{NO}_{3}{ }^{-}$was significantly greater in the sugar maplebasswood ecosystem $(96 \%)$ than in the sugar maplered oak ecosystem (52\%). Within each ecosystem, gross nitrification rates were significantly related to gross $\mathrm{N}$ mineralization rates (Fig. 8).

\section{Summary of clear-cutting effects on internal soil nitrogen dynamics}

The effects of clear-cut harvesting on pools and gross transformation rates of $\mathrm{N}$ (averaged over the growing season) are summarized in Fig. 9. In both ecosystems, clear-cutting led to increased gross rates of $\mathrm{N}$ mineralization, nitrification, and $\mathrm{NO}_{3}{ }^{-}$immobilization. Because gross immobilization of $\mathrm{NH}_{4}{ }^{+}$and $\mathrm{NO}_{3}{ }^{-}$was only a fraction of gross nitrification, large amounts of $\mathrm{NO}_{3}{ }^{-}$accumulated in soil solution, which eventually contributed to high rates of leaching from clear-cut plots in both ecosystems. However, clear-cutting effects differed between ecosystems. In the sugar maplered oak ecosystem, gross $\mathrm{N}$ mineralization increased threefold (74 and $221 \mathrm{mg} \mathrm{N} \cdot \mathrm{m}^{-2} \cdot \mathrm{d}^{-1}$, intact and clearcut, respectively) and gross nitrification increased by a factor of 2.4 (40 and $96 \mathrm{mg} \mathrm{N} \cdot \mathrm{m}^{-2} \cdot \mathrm{d}^{-1}$ for intact and clear-cut, respectively). In the sugar maple-basswood ecosystem, however, gross $\mathrm{N}$ mineralization increased by a factor of $1.5\left(91\right.$ and $140 \mathrm{mg} \mathrm{N} \cdot \mathrm{m}^{-2} \cdot \mathrm{d}^{-1}$ for intact and clear-cut, respectively) as did gross nitrification (80 and $135 \mathrm{mg} \mathrm{N} \cdot \mathrm{m}^{-2} \cdot \mathrm{d}^{-1}$ for intact and clear-cut, respectively).

Interestingly, the source of $\mathrm{N}$ immobilized differed between the two ecosystems prior to clear-cutting. In the sugar maple-red oak ecosystem, $\mathrm{N}$ was immobilized mainly from the soil $\mathrm{NH}_{4}{ }^{+}$pool, whereas in the sugar maple-basswood ecosystem, $\mathrm{NO}_{3}{ }^{-}$immobilization exceeded $\mathrm{NH}_{4}{ }^{+}$immobilization. Following harvest, however, rates of $\mathrm{NO}_{3}{ }^{-}$immobilization were equivalent between ecosystems. Although clear-cutting stimulated microbial activity, it had no significant effect on the pool of microbial N. Because N immobilization increased in the clear-cut plots, the mean residence time (MRT) of $\mathrm{N}$ in microbial biomass decreased relative to intact plots in both ecosystems (e.g., from 1393 to $704 \mathrm{~d}$ in sugar maple-basswood and from 369 to $172 \mathrm{~d}$ in sugar maple-red oak). The shorter MRT of microbial $\mathrm{N}$ in the sugar maple-red oak ecosystem indicates more rapid turnover of a smaller pool of microbial biomass.

\section{DISCUSSION}

The effects of forest harvesting on $\mathrm{N}$ loss vary among forest ecosystems that differ in rates of $\mathrm{N}$ cycling. For example, hardwood forests are often more susceptible to $\mathrm{N}$ loss than are coniferous forests following harvesting, because they have greater rates of $\mathrm{N}$ mineralization and nitrification, as well as lower litter C:N (Vitousek et al. 1982). However, we have a limited understanding of the extent to which microbial immobilization functions as a temporary sink for $\mathrm{N}$ following the harvest of northern hardwood forests, thus reducing the potential for $\mathrm{N}$ loss to groundwater or the atmosphere. In the forests we studied, microbial $\mathrm{N}$ immobilization can retain substantial quantities of $\mathrm{N}$ during early spring, a time when plant $\mathrm{N}$ uptake is minimal and the potential for $\mathrm{NO}_{3}{ }^{-}$leaching is high (Zak et al. 1990). This suggests that microbial immobilization of $\mathrm{N}$ could act as a short-term mechanism of $\mathrm{N}$ retention following harvesting. However, our results indicate that $\mathrm{N}$ immobilization is of minimal importance following 
Intact

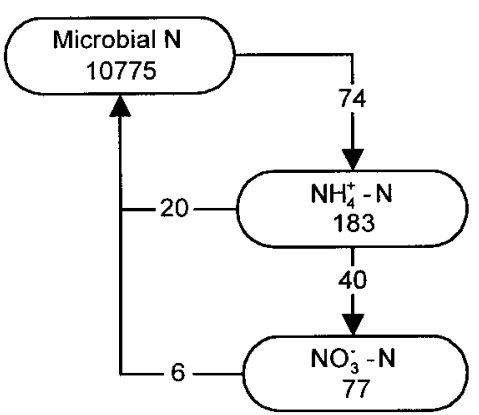

Clear-cut

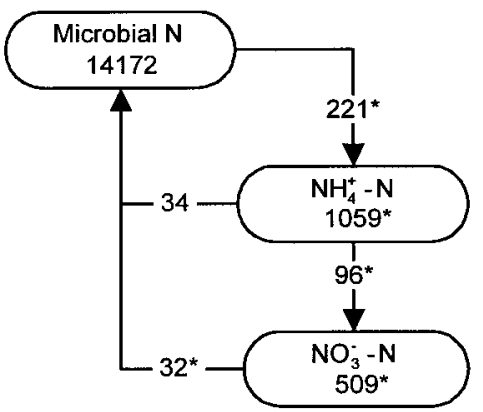

Sugar maple-basswood

Intact

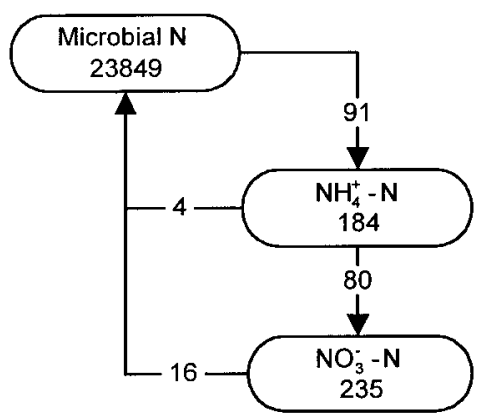

Clear-cut

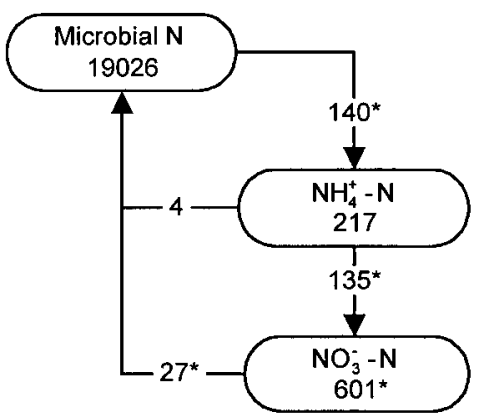

FIG. 9. Soil $\mathrm{N}$ pools and gross rates of $\mathrm{N}$ transformations in intact and clear-cut plots within two northern hardwood ecosystems. Values are growing season means $(n=8)$ derived from 5-d laboratory soil incubations with ${ }^{15} \mathrm{~N}$ in April, June, August, and October 1992. Nitrogen pools, designated by oval shapes, are in units of $\mathrm{mg} \mathrm{N} / \mathrm{m}^{2}$. Arrows between pools designate gross rates of $\mathrm{N}$ mineralization (microbial $\mathrm{N} \rightarrow \mathrm{NH}_{4}{ }^{+}-\mathrm{N}$ ), nitrification $\left(\mathrm{NH}_{4}{ }^{+} \mathrm{N}^{-} \rightarrow \mathrm{NO}_{3}{ }^{-} \mathrm{N}\right.$ ), and $\mathrm{N}$ immobilization $\left(\mathrm{NH}_{4}{ }^{+} \mathrm{N}+\mathrm{NO}_{3}{ }^{-} \mathrm{N} \rightarrow\right.$ microbial $\left.\mathrm{N}\right)$, expressed in units of $\mathrm{mg} \mathrm{N} \cdot \mathrm{m}^{-2} \cdot \mathrm{d}^{-1}$. Clear-cut plot means designated by asterisks $(*)$ differ significantly from intact plot means of the same ecosystem (Tukey's HSD, $P<0.05$ ).

harvesting in sugar maple-dominated northern hardwood ecosystems. In fact, overstory removal caused a dramatic increase in the cycling of $\mathrm{N}$ through microbial biomass, resulting in increased $\mathrm{NH}_{4}^{+}$availability in soil, greater rates of nitrification, and substantial leaching losses of $\mathrm{NO}_{3}{ }^{-}$. Moreover, the initial difference in nitrification rates between northern hardwood ecosystems did not result in differences in $\mathrm{N}$ loss following harvesting, suggesting that floristically and edaphically distinct ecosystems can respond in ways that lead to similar $\mathrm{N}$ losses.

\section{Nitrate leaching}

Clear-cutting led to equivalent losses of $\mathrm{N}$ through $\mathrm{NO}_{3}{ }^{-}$leaching from both ecosystems, averaging $4.9 \mathrm{~g} \mathrm{NO}_{3}^{-}-\mathrm{N} \cdot \mathrm{m}^{-2} \cdot \mathrm{yr}^{-1}$ in clear-cut plots and $0.19 \mathrm{~g}$ $\mathrm{NO}_{3}{ }^{-}-\mathrm{N} \cdot \mathrm{m}^{-2} \cdot \mathrm{yr}^{-1}$ in intact plots. The former rate is among the highest reported from harvested forest ecosystems, and it is comparable to the first-year annual loss measured in streamflow outputs from block clearcut northern hardwoods at Hubbard Brook Experimental Forest (4.0 $\mathrm{g} \mathrm{NO}_{3}^{-}-\mathrm{N} \cdot \mathrm{m}^{-2} \cdot \mathrm{yr}^{-1}$; Hornbeck et al. 1986).
The greatest rates of $\mathrm{NO}_{3}{ }^{-}$leaching from clear-cut plots occurred during autumn, subsequent to high rates of nitrification and the accumulation of $\mathrm{NO}_{3}{ }^{-}$in soil solution during summer. This pattern of elevated soil $\mathrm{NO}_{3}{ }^{-}$concentration during autumn is similar in timing and magnitude to that observed in trenched northern hardwood plots in New Hampshire by Vitousek et al. (1982). The timing of $\mathrm{NO}_{3}{ }^{-}$leaching is controlled by water yield (i.e., precipitation and AET) and soil water $\mathrm{NO}_{3}{ }^{-}$concentrations. The pulse of leaching in early spring resulted from high water yield during snowpack ablation (Fig. 2B). Although soil $\mathrm{NO}_{3}{ }^{-}$concentrations increased during the summer, leaching was minimal due to low water yield. By the end of the summer, accumulated $\mathrm{NO}_{3}{ }^{-}$in the clear-cut plots began appearing in lysimeters $1 \mathrm{~m}$ below the soil surface. Most $\mathrm{NO}_{3}{ }^{-}$leaching occurred between September and November, a period when nearly $50 \%$ of the annual water yield coincided with high lysimeter $\mathrm{NO}_{3}{ }^{-}$concentrations in the clear-cut plots (Fig. 2, average $13 \mathrm{mg}$ N/L).

Total $\mathrm{NO}_{3}{ }^{-}$losses through leaching appear to be driven by factors regulating soil $\mathrm{NO}_{3}{ }^{-}$concentration, as 
opposed to water yield, which mainly affects the timing of losses. Although our assumption of $29 \%$ greater annual water yield in clear-cut plots is comparable to water yield increases observed in clear-cut northern hardwoods at Hubbard Brook (16-36\%; Hornbeck et al. 1987, Dahlgren and Driscoll 1994), this assumption may be questionable because it was based on results from forests in other geographic regions. However, even if water yield were unaffected by clear-cutting, annual $\mathrm{NO}_{3}{ }^{-}$loss would still be far greater in clear-cut than in intact plots (4.23 vs. $0.19 \mathrm{~g} \mathrm{~N} \cdot \mathrm{m}^{-2} \cdot \mathrm{yr}^{-1}$, respectively).

Rates of $\mathrm{NO}_{3}{ }^{-}$leaching and lysimeter $\mathrm{NO}_{3}{ }^{-}$concentrations within clear-cut plots were notably lower in one stand in the sugar maple-basswood ecosystem. This does not appear to be due to a difference in vegetation, soil, or $\mathrm{N}$ transformation rates from the other stands, but may be related to a difference in physiography. The slope is much steeper in this stand $(>15 \%$ vs. $<6 \%$ in all other stands). Lateral flow of water through sandy-textured surface soil horizons can account for a significant proportion of total (lateral and vertical) water movement on hillslopes (Gaskin et al. 1989). If a portion of $\mathrm{NO}_{3}{ }^{-}$carried in soil water were diverted laterally (downslope) through horizons above the depth of the lysimeters $(1 \mathrm{~m})$, then rates of $\mathrm{NO}_{3}{ }^{-}$ leaching observed at this site would have been underestimated.

\section{Denitrification}

Denitrification was not an important mechanism of $\mathrm{N}$ loss following clear-cut harvest in either northern hardwood ecosystem. The mean annual rates of denitrification that we observed are within the range of 0.06-1.8 $\mathrm{g} \mathrm{N}_{2} \mathrm{O}-\mathrm{N} \cdot \mathrm{m}^{-2} \cdot \mathrm{yr}^{-1}$ measured in well-drained upland forest soils of Lower Michigan (Groffman and Tiedje 1989). In a study of upland and wetland ecosystems, Merrill (1991) also found greater rates of denitrification in the sugar maple-basswood ecosystem than in the sugar maple-red oak ecosystem, but $\mathrm{N}$ losses via this process also were low.

The absence of a clear-cutting effect on denitrification is somewhat unexpected, given the increases in soil water content and $\mathrm{NO}_{3}{ }^{-}$availability. Brumme (1995) found that elevated denitrification in overstory gaps within a Fagus sylvatica-dominated forest two years following clear-cut $\left(0.29 \mathrm{~g} \mathrm{~N}_{2} \mathrm{O}-\mathrm{N} / \mathrm{m}^{2}\right.$ in six months) was related to an increase in soil water content. Under experimental conditions in the laboratory, Merrill and Zak (1992) demonstrated that denitrification rate increases with soil water content, labile $\mathrm{C}$ availability, and $\mathrm{NO}_{3}{ }^{-}$availability, all of which would be expected to increase in the clear-cut plots. However, if denitrification in upland forest soils is limited to favorable sites at or very near the soil surface (Parkin 1987), then denitrification in the clear-cut plots may have been constrained by low soil water or $\mathrm{NO}_{3}{ }^{-}$availability at the soil surface. These sandy, poorly struc- tured soils probably have few microsites able to support denitrification, even in the presence of ample substrate (i.e., $\mathrm{NO}_{3}{ }^{-}$and organic $\mathrm{C}$ ). It appears that exposure to wind and insolation in clear-cut plots during dry periods dessicated the soil surface, whereas vertical water flow during wet periods transported $\mathrm{NO}_{3}{ }^{-}$deeper into soil profile, thus limiting denitrification in the surface soil of clear-cut plots.

\section{Microbial activity and internal soil nitrogen dynamics}

Changes in soil $\mathrm{N}$ transformations following clearcut harvest illustrate the importance of soil microbial processes in controlling ecosystem patterns of $\mathrm{N}$ loss. We found that greater rates of net $\mathrm{N}$ mineralization, nitrification, and the subsequent accumulation of $\mathrm{NO}_{3}{ }^{-}$in soil solution corresponded to increased soil water content and temperature following clear-cut harvest. These changes in physical site conditions, combined with changes in substrate availability, led to more rapid turnover of microbial $\mathrm{N}$ and more rapid rates of net $\mathrm{N}$ mineralization. In turn, high rates of net $\mathrm{N}$ mineralization led to greater rates of nitrification and, ultimately, $\mathrm{NO}_{3}^{-}$leaching.

Elevated nitrification and $\mathrm{NO}_{3}{ }^{-}$leaching following disturbance have been linked to accelerated decomposition of labile organic matter in forests having litter of relatively high $\mathrm{N}$ content (Vitousek et al. 1982). Northern hardwood forests are particularly susceptible to $\mathrm{N}$ loss following harvest, because the litter chemistry of dominant species, such as sugar maple, promotes rapid decomposition (Nadelhoffer et al. 1983). Studies of harvesting in northern hardwoods have consistently reported significant increases in $\mathrm{N}$ transformation rates, based upon forest floor incubations (Fisk and Fahey 1990, Duggin et al. 1991) and changes in soil inorganic N pools (Dahlgren and Driscoll 1994). Our results concur with these findings and with observations that decomposition rates increase with soil water content, temperature, and substrate availability (Aber et al. 1978, Vitousek et al. 1982, Edwards and Ross-Todd 1983).

Greater soil moisture, temperature, and substrate availability in the clear-cut plots favored higher rates of gross $\mathrm{N}$ mineralization and more rapid turnover of microbial N (e.g., lower MRT). In turn, greater soil heterotrophic activity resulted in higher rates of net $\mathrm{N}$ mineralization, because rates of gross $\mathrm{N}$ mineralization were three to four times greater than rates of gross $\mathrm{N}$ immobilization. It appears that substrate quality for microbial metabolism did not change in either ecosystem following clear-cut, because $\mathrm{N}$ immobilization remained a constant proportion of gross $\mathrm{N}$ mineralization. Toland and Zak (1994) found that soil respiration did not differ between intact and clear-cut plots (mean =

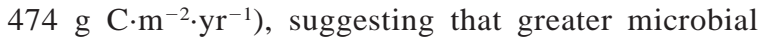
respiration in the clear-cut plots compensated for reduced respiration of live roots. Increases in substrate availability for heterotrophic activity, in combination 
with changes in environmental factors that enhanced rates of microbial activity, led to more rapid rates of $\mathrm{N}$ transformations in soil and created the potential for $\mathrm{N}$ loss.

\section{Nitrogen immobilization}

In the northern hardwood ecosystems that we studied, immobilization of $\mathrm{N}$ was not an important process preventing $\mathrm{N}$ loss following clear-cut harvest. Microbial biomass did not increase significantly in the clearcut plots and, thus, did not serve as a temporary sink for $\mathrm{N}$ following overstory removal. Rather, greater rates of gross $\mathrm{N}$ immobilization in the clear-cut plots reflect greater microbial activity and more rapids rates of $\mathrm{N}$ turnover. Vitousek and Matson (1985) found that $\mathrm{N}$ immobilization was an important process of $\mathrm{N}$ retention following clear-cut of a loblolly pine plantation. They demonstrated the importance of organic matter in regulating $\mathrm{N}$ retention in these sites by experimental removal of the forest floor and logging debris, which caused lower rates of $\mathrm{N}$ immobilization and greater rates of $\mathrm{NO}_{3}{ }^{-}$leaching. Although the chemistry of organic matter in such forests prevents $\mathrm{N}$ loss by promoting $\mathrm{N}$ immobilization, the chemistry of organic matter in the northern hardwood ecosystems that we studied may actually contribute to $\mathrm{N}$ loss by promoting gross $\mathrm{N}$ mineralization more than gross $\mathrm{N}$ immobilization.

\section{Nitrogen mineralization}

Compared to the sugar maple-basswood ecosystem, rates of net $\mathrm{N}$ mineralization and nitrification increased to a greater degree following clear-cut in the sugar maple-red oak ecosystem, which had lower nitrification rates prior to harvest. The differential response of net $\mathrm{N}$ mineralization to harvesting in these ecosystems is most likely related to the distribution and quality of soil organic matter prior to harvest. In the sugar maplered oak ecosystem, the soil had lower $\mathrm{C}$ and $\mathrm{N}$ contents and higher $\mathrm{C}: \mathrm{N}$ (Table 1), soil microbial biomass was smaller and more dynamic (as indicated by MRT of microbial $\mathrm{N}$ ), and there was more organic matter in the forest floor compared to the sugar maple-basswood ecosystem. After clear-cut harvest in the sugar maplered oak ecosystem, disturbance to the forest floor probably enhanced transfer of labile forms of organic matter into the surface soil. Such an input of organic substrate into the soil may have contributed to the more pronounced increase in net $\mathrm{N}$ mineralization following harvesting in this ecosystem.

\section{Nitrification}

In the sugar maple-basswood ecosystem, nitrification increased concurrently with $\mathrm{N}$ mineralization, resulting in relatively large $\mathrm{NO}_{3}{ }^{-}$pools in soil solution, particularly during the summer. The lack of soil $\mathrm{NH}_{4}{ }^{+}$accumulation in clear-cut plots of this ecosystem indicates that there was no delay in nitrification fol- lowing accelerated net $\mathrm{N}$ mineralization rates. In contrast, soil $\mathrm{NH}_{4}^{+}$accumulated to very high concentrations in the clear-cut plots of the sugar maple-red oak ecosystem, and there appeared to be a 1-mo delay in nitrification. After midsummer, however, net nitrification rates increased and the proportion of mineralized $\mathrm{N}$ oxidized to $\mathrm{NO}_{3}{ }^{-}$approached that of the sugar maple-basswood clear-cut plots. This suggests that nitrification in the sugar maple-red oak ecosystem is constrained by factors other than soil $\mathrm{NH}_{4}{ }^{+}$availability. A delay in nitrification may have resulted from low initial populations of nitrifying bacteria, or from labile inhibitors of nitrification (Robertson 1982, Vitousek and Matson 1985).

Nitrifying bacteria were apparently not limited by competition with soil heterotrophs for $\mathrm{NH}_{4}{ }^{+}$in the clear-cut plots. Soil heterotrophs produced more $\mathrm{NH}_{4}{ }^{+}$than they assimilated, because gross rates of $\mathrm{N}$ mineralization greatly exceeded $\mathrm{N}$ immobilization. Also, most of the increase in $\mathrm{N}$ immobilization resulted from immobilization of $\mathrm{NO}_{3}{ }^{-}$, rather than $\mathrm{NH}_{4}{ }^{+}$(Fig. 9: $\mathrm{N}$ flow chart). Greater rates of $\mathrm{NO}_{3}{ }^{-}$immobilization corresponded to greater soil $\mathrm{NO}_{3}{ }^{-}$concentrations, suggesting that the increased demands of microbial growth for $\mathrm{N}$ were met by the availability of $\mathrm{NO}_{3}{ }^{-}$. Hart et al. (1994) suggested that, although heterotrophs assimilate $\mathrm{NH}_{4}{ }^{+}$preferentially, $\mathrm{NO}_{3}{ }^{-}$assimilation may occur within soil microsites where $\mathrm{C}$ availability is high and $\mathrm{NH}_{4}{ }^{+}$becomes depleted.

\section{SUMMARY AND IMPLICATIONS}

In the two northern hardwood ecosystems that we studied, clear-cut harvesting resulted in similar rates of $\mathrm{N}$ loss, although the ecosystems initially differed in patterns and rates of $\mathrm{N}$ cycling. Net $\mathrm{N}$ mineralization increased to equivalent rates following harvesting in both ecosystems. Greater rates of net $\mathrm{N}$ mineralization resulted from large increases in gross rates of $\mathrm{N}$ mineralization, whereas gross rates of $\mathrm{N}$ immobilization increased to a much smaller extent. This significant, but small, increase in gross $\mathrm{N}$ immobilization did not increase the pool of microbial $\mathrm{N}$. Consequently, microbial biomass was not an important sink for $\mathrm{N}$, following harvesting, in either ecosystem.

Differences in nitrification rates between the ecosystems prior to harvest were not related to rates of $\mathrm{NO}_{3}{ }^{-}$leaching following overstory removal. Our results indicate that the response of nitrification to harvesting and, thus, the potential for $\mathrm{NO}_{3}^{-}$leaching in these ecosystems, is regulated primarily by changes in net $\mathrm{N}$ mineralization. Therefore, an understanding of landscape patterns of nitrification among northern hardwood forests cannot be used to predict $\mathrm{N}$ loss following harvesting. Given the similarity between our results and those from studies of harvesting in other northern hardwood forests, it appears that northern hardwood ecosystems with high rates of net $\mathrm{N}$ min- 
eralization are highly susceptible to $\mathrm{N}$ loss following harvesting.

\section{ACKNOWLEDGMENTS}

This manuscript is based on the dissertation completed by the senior author at the University of Michigan School of Natural Resources and Environment. We thank Matt Sands, Rose Ingram, and Dave Reff of the Manistee National Forest, USDA Forest Service, for their technical advice and logistical support in coordinating the harvesting of our experimental plots. Bob Doherty, Dawn Majewski, Amy Merrill, David Toland, and Mark Zaroff provided generous help with fieldwork. Bette Stallman, Jeff Hacala, Nanci Walker, and Kelly Caldwell contributed many hours of help with laboratory work. We appreciate the helpful advice and comments of Burt Barnes, Melany Fisk, Bob Fogel, Gary Fowler, Neil MacDonald, and Sandy Verry during preparation of this manuscript. This research was funded by McIntire-Stennis Cooperative Forestry Research Act (PL 87-788). We also acknowledge support from Rackham School of Graduate Studies at the University of Michigan.

\section{Literature Cited}

Aber, J. D., D. B. Botkin, and J. M. Melillo. 1978. Predicting the effects of different harvesting regimes on forest floor dynamics in northern hardwood forests. Canadian Journal of Forest Research 8:308-316.

Albert, D. A., S. R. Denton, and B. V. Barnes. 1986. Regional landscape ecosystems of Michigan. School of Natural Resources, University of Michigan, Ann Arbor, Michigan, USA.

Barnes, B. V., K. S. Pregitzer, T. A. Spies, and V. H. Spooner. 1982. Ecological forest site classification. Journal of Forestry 80:493-498.

Bormann, F. H., and G. E. Likens. 1979. Pattern and process in a forested ecosystem. Springer-Verlag, New York, New York, USA.

Brooks, P. D., J. M. Stark, B. B. McInteer, and T. Preston 1989. Diffusion method to prepare soil extracts for automated nitrogen-15 analysis. Soil Science Society of America Journal 53:1707-1711.

Brumme, R. 1995. Mechanisms of carbon and nutrient release and retention in beech forest gaps. Plant and Soil 168-169:593-600.

Christensen, N. L., et al. 1996. The report of the Ecological Society of America Committee on the scientific basis for ecosystem management. Ecological Applications 6:665691.

Dahlgren, R. A., and C. T. Driscoll. 1994. The effects of whole-tree clear-cutting on soil processes at the Hubbard Brook Experimental Forest, New Hampshire, USA. Plant and Soil 158:239-262.

Davidson, E. A, S. C. Hart, and M. K. Firestone. 1992. Internal cycling of nitrate in soils of a mature coniferous forest. Ecology 73:1148-1156.

Davidson, E. A, S. C. Hart, C. A. Shanks, and M. K. Firestone. 1991. Measuring gross nitrogen mineralization, immobilization, and nitrification by $15-\mathrm{N}$ isotopic pool dilution in intact soil cores. Journal of Soil Science 42:335-349.

Duggin, J. A., G. K. Vogt, and F. H. Bormann. 1991. Autotrophic and heterotrophic nitrification in response to clearcutting northern hardwood forest. Soil Biology and Biochemistry 23:779-787.

Edwards, N. T., and B. M. Ross-Todd. 1983. Soil carbon dynamics in a mixed deciduous forest following clear-cutting with and without residue removal. Soil Science Society of America Journal 47:1014-1021.

Eno, C. F. 1960. Nitrate production in the field by incubating soil in polyethylene bags. Soil Science Society of America Proceedings 24:227-279.
Federer, C. A., J. W. Hornbeck, L. M. Tritton, C. W. Martin, R. S. Pierce, and C. T. Smith. 1989. Long-term depletion of calcium and other nutrients in eastern U.S. forests. Environmental Management 13:593-601.

Fisk, M. F., and T. J. Fahey. 1990. Nitrification potential in the organic horizons following clear-felling of northern hardwood forests. Soil Biology and Biochemistry 22:277279.

Gale, M. R., and D. F. Grigal. 1987. Vertical root distributions of northern tree species in relation to successional status. Canadian Journal of Forest Research 17:829-834.

Gaskin, J. W., J. F. Dowd, W. L. Nutter, and W. T. Swank. 1989. Vertical and lateral components of soil nutrient flux in a hillslope. Journal of Environmental Quality 18:403410.

Groffman, P. M., and J. M. Tiedje. 1989. Denitrification in north temperate forest soils: spatial and temporal patterns at the landscape and seasonal scales. Soil Biology and Biochemistry 21:613-620.

Hart, S. C., G. E. Nason, D. D. Myrold, and D. A. Perry. 1994. Dynamics of gross transformation in an old-growth forest: the carbon connection. Ecology 75:880-891.

Holmes, W. E., and D. R. Zak. 1994. Soil microbial biomass dynamics and net nitrogen mineralization in northern hardwoods. Soil Science Society of America Journal 58:238243.

Hornbeck, J. W., M. B. Adams, E. S. Corbett, E. S. Verry, and J. A. Lynch. 1993. Long-term impacts of forest treatments on water yield: a summary for northeastern USA. Journal of Hydrology 150:323-344.

Hornbeck, J. W., and W. Kropelin. 1982. Nutrient removal and leaching from a whole-tree harvest of northern hardwoods. Journal of Environmental Quality 11:309-316.

Hornbeck, J. W., C. W. Martin, R. S. Pierce, F. H. Bormann, G. E. Likens, and J. S. Eaton. 1986. Clearcutting northern hardwoods: effects on hydrologic and nutrient ion budgets. Forest Science 32:667-686.

Hornbeck, J. W., C. W. Martin, R. S. Pierce, F. H. Bormann, G. E. Likens and J. S. Eaton. 1987. The northern hardwood forest ecosystem: ten years of recovery from clearcutting. U.S. Forest Service, Northeastern Forest Experiment Station Publication NE-RP-596.

Kirkham, D., and W. V. Bartholomew. 1954. Equations for following nutrient transformations in soil, utilizing tracer data. Soil Science Society of America Proceedings 18:3334.

MacDonald, N. W., A. J. Burton, H. O. Liechty, J. A. Witter, K. S. Pregitzer, G. D. Mroz, and D. D. Richter. 1992. Ion leaching in forest ecosystems along a Great Lakes air pollution gradient. Journal of Environmental Quality 21:614623.

Merrill, A. G. 1991. Factors controlling temporal fluxes of denitrification and nitrate leaching in upland and swamp forests. Thesis. University of Michigan, Ann Arbor, Michigan, USA.

Merrill, A. G., and D. R. Zak. 1992. Factors controlling denitrification in upland and swamp forests. Canadian Journal of Forest Research 22:1597-1604.

Nadelhoffer, K. J., J. D. Aber, and J. M. Melillo. 1983. Leaflitter production and soil organic matter dynamics along a nitrogen-availability gradient in Southern Wisconsin (U.S.A.). Canadian Journal of Forest Research 13:12-21.

Netter, J., W. Wasserman, and M. H. Kutner. 1990. Applied linear statistical models. Third edition. Irwin, Homewood, Illinois, USA.

Parkin, T. B. 1987. Soil microsites as a source of denitrification variability. Soil Science Society of America Journal 51:1194-1199.

Parkin, T. B., H. F. Kaspar, A. J. Sexstone, and J. M. Tiedje. 1984. A gas-flow soil core method to measure field de- 
nitrification rates. Soil Biology and Biochemistry 16:323330.

Pastor, J., J. D. Aber, C. A. McClaugherty, and J. M. Melillo. 1984. Aboveground production and $\mathrm{N}$ and $\mathrm{P}$ cycling along a nitrogen mineralization gradient on Blackhawk Island, Wisconsin. Ecology 65:256-268.

Robertson, G. P. 1982. Factors regulating nitrification in primary and secondary succession. Ecology 63:1561-1573.

Rolston, D. E., P. S. C. Rao, J. M. Davidson, and R. E. Jessup. 1984. Simulation of denitrification losses of nitrate fertilizer applied to uncropped, cropped, and manure-amended field plots. Soil Science 137:270-279.

Smith, J. L., and E. A. Paul. 1990. The significance of soil microbial biomass estimations. Pages 357-396 in J.-M. Bollag and G. Stotzky, editors. Soil biochemistry. Volume 6. Dekker, New York, New York, USA.

Thornthwaite, C. W., and J. R. Mather. 1957. Instructions and tables for computing potential evapotranspiration and the water balance. Climatology 10:185-311.

Tiedje, J. M. 1982. Denitrification. Pages 1011-1026 in A. L. Page, editor. Methods of soil analysis. Part 2. American Society of Agronomy, Madison, Wisconsin, USA.

Tiedje, J. M., S. Simkins, and P. M. Groffman. 1989. Perspectives on measurement of denitrification in the field including recommended protocols for acetylene-based methods. Plant and Soil 115:261-284.

Toland, D. E., and D. R. Zak. 1994. Seasonal patterns of soil respiration in intact and clear-cut northern hardwood forests. Canadian Journal of Forest Research 24:17111716
Verry, E. S. 1987. The effect of aspen harvest and growth on water yield in Minnesota. Forest Hydrology and Watershed Management 167:553-562.

Vitousek, P. M., J. R. Gosz, C. C. Grier, J. M. Melillo, and W. A. Reiners. 1982. A comparative analysis of potential nitrification and nitrate mobility in forest ecosystems. Ecological Monographs 52:155-177.

Vitousek, P. M., and P. A. Matson. 1985. Disturbance, nitrogen availability, and nitrogen losses in an intensively managed loblolly pine plantation. Ecology 66:1360-1376.

Voroney, R. P., and E. A. Paul. 1984. Determination of $k_{c}$ and $k_{n}$ in situ for calibration of the chloroform fumigationincubation method. Soil Biology and Biochemistry 16:914.

Wilkinson, L. 1990. SYSTAT: the system for statistics. SYSTAT, Evanston, Illinois, USA.

Zak, D. R., P. M. Groffman, K. S. Pregitzer, S. Christensen, and J. M. Tiedje. 1990. The vernal dam: plant-microbe competition for nitrogen in northern hardwood forests. Ecology 71:651-656.

Zak, D. R., G. E. Host, and K. S. Pregitzer. 1989. Regional variability in nitrogen mineralization, nitrification, and overstory biomass in northern lower Michigan. Canadian Journal of Forest Research 19:1521-1526.

Zak, D. R., and K. S. Pregitzer. 1990. Spatial and temporal variability in nitrogen cycling in northern lower Michigan. Forest Science 36:367-380.

Zak, D. R., K. S. Pregitzer, and G. E. Host. 1986. Landscape variation in nitrogen mineralization and nitrification. Canadian Journal of Forest Research 16:1258-1263. 